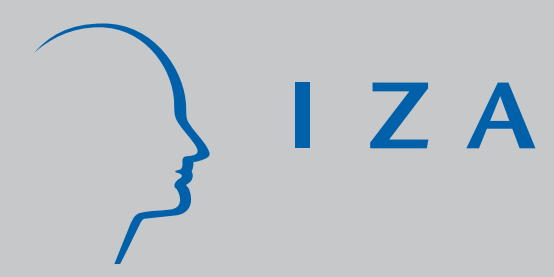

IZA DP No. 2094

Welfare Migration in Europe and the Cost of a Harmonised Social Assistance

Giacomo De Giorgi Michele Pellizzari

April 2006 


\title{
Welfare Migration in Europe and the Cost of a Harmonised Social Assistance
}

\author{
Giacomo De Giorgi \\ University College London \\ Michele Pellizzari \\ IGIER-Bocconi and IZA Bonn
}

Discussion Paper No. 2094

April 2006

IZA
P.O. Box 7240
53072 Bonn
Germany

Phone: +49-228-3894-0

Fax: +49-228-3894-180

Email: iza@iza.org

\begin{abstract}
Any opinions expressed here are those of the author(s) and not those of the institute. Research disseminated by IZA may include views on policy, but the institute itself takes no institutional policy positions.

The Institute for the Study of Labor (IZA) in Bonn is a local and virtual international research center and a place of communication between science, politics and business. IZA is an independent nonprofit company supported by Deutsche Post World Net. The center is associated with the University of Bonn and offers a stimulating research environment through its research networks, research support, and visitors and doctoral programs. IZA engages in (i) original and internationally competitive research in all fields of labor economics, (ii) development of policy concepts, and (iii) dissemination of research results and concepts to the interested public.
\end{abstract}

IZA Discussion Papers often represent preliminary work and are circulated to encourage discussion. Citation of such a paper should account for its provisional character. A revised version may be available directly from the author. 


\section{ABSTRACT \\ Welfare Migration in Europe and the Cost of a Harmonised Social Assistance*}

The enlargement of the European Union has increased concerns about the role of generous welfare transfers in attracting migrants. This paper explores the issue of welfare migration across the 15 countries of the pre-enlargement Union and finds a significant but small effect of the generosity of welfare on migration decisions. This effect, however, is still large enough to distort the distribution of migration flows and, possibly, offset the potential benefits of migration as an inflow of mobile labour into countries with traditionally sedentary native workers. A possible way to eliminate these distortions is the harmonisation of welfare at the level of the Union. The second part of the paper estimates the costs and benefits of what could be a first step in this direction: the introduction of a uniform European minimum income. The results show that, for a realistic minimum income threshold, the new system would cost about three quarters of what is currently spent on housing and social assistance benefits. Despite its reasonable cost, the distribution of net donors and net receivers across countries is such that the actual implementation of this system would be politically problematic.

JEL Classification: J61

Keywords: $\quad$ EU enlargement, migration, welfare state

Corresponding author:

Giacomo De Giorgi

University College London

Drayton House

Gordon Street

London WC1H OAX

United Kingdom

Email: g.degiorgi@ucl.ac.uk

\footnotetext{
* Our special thanks go to Giovanna Albano, Francesco Fasani, Mauro Maggioni and Sara Pinoli who have substantially contributed to this project with skillful assistance and comments. We would also like to thank all seminar participants at the University of Verona, the University of Salerno, the Barcelona ENTER conference and the XX AIEL conference in Rome. Tito Boeri, Rodolfo Helg, Francesca Mazzolari and all participants to the EU-funded FLOWENLA Project provided important comments and suggestions. All errors are our own responsibility. Financial support from Bocconi University is gratefully acknowledged.
} 


\section{Introduction}

The most recent projections (Alvarez-Plata et al. (2003)) indicate that, in the absence of any restriction to the free movement of persons, the enlargement of the European Union should generate a flow of approximately 200,000 persons from the accession countries into the pre-enlargement Union, with a long-run stock of 2.3 million persons. The effects of such an increase in migration have been recently analysed by academics as well as policy makers (Boeri et al. (2001), Sinn (1999)). Among other considerations, much concern has risen about the impact of larger migration flows on the welfare state institutions of the receiving countries (see Kvist (2004), Sinn(2004a), Sinn (2004b)).

This paper estimates the extent to which welfare generosity affects the location decisions of migrants in the 15 countries of the pre-enlargement Union, and moving from such estimates we compute the cost of a harmonised European minimum income programme.

Migration from Eastern Europe can have both positive and negative effects on the economies of the receiving countries. On the one hand, the enlargement, involving countries with younger and growing populations, is expected to alleviate the financial strain of many countries' public pension systems. On the other hand, since migrants use the welfare state relatively more than native citizens (Boeri et al. (2000)), they may also increase pressure on its sustainability. Hence, immigration could be potentially driven, among other things, also by the generosity of the welfare system. The large variation in the welfare institutions of the pre-enlargement 15 European countries could, then, distort the distribution of migration flows.

This is a very important issue because an efficient distribution of migration flows would be extremely beneficial for the European labour markets. In fact, contrary to the United States, European workers are very immobile, making it difficult for the economy to adjust to asymmetric changes in labour demand. This is particularly true after the introduction of the Euro, that eliminated the exchange rates, an instrument that has been normally used in the past for stabilizing the economy after asymmetric shocks.

Almost by definition, migrants are a very mobile form of labour and, as long as they move into areas where labour is scarce and wages are high, they can play a crucial role in counterbalancing the low mobility of native European workers. High wages and high employment probabilities, rather than the generosity of welfare, should be the main driving forces of migration. 
Put in other words, to the extent that migrants from eastern Europe choose their destination on the basis of the generosity of welfare, the potential benefits of acquiring a more mobile labour force will be lost. Moreover the costs (in terms of higher social expenditure) of the expected larger migration flows will be unevenly distributed, to the expenses of countries and regions where financial pressure on welfare is already high.

The issue of welfare induced migration has already received a good deal of attention in the economic literature. Early studies were generally based on aggregate data and showed that states with more generous benefits were also associated with slightly larger inflows of migrants. With aggregate data, however, it is impossible to focus on those subgroups of the population (large families, single parents, women, etc.) who are more likely to consider the generosity of welfare an important element in their migration decisions. Using micro data at a more disaggregated level other authors (Blank (1988), Borjas (1999), Gramlich et al. (1984), Meyer (2000)) still found a significant impact of welfare on migration. Even the most recent strand of papers (McKinnish(2005), Gelbach (2004), Walker (1994)), that rely on difference-in-difference methods, confirm the existence of some welfare migration, especially for the most vulnerable groups of the population. Nevertheless, these effects are generally considered too small to seriously affect policy making.

All these studies, however, are based on the United States, where labour mobility is relatively high for native workers as well and the role of migration as a stabilizer after asymmetric shocks is somewhat less important. This paper focuses on Europe and shows that the effect of welfare generosity can be large enough to offset the changes in migration patterns that would arise from an asymmetric shock to unemployment.

Besides its focus on geographical labour reallocation, this paper also contributes to the literature by providing the first estimates of welfare migration across European countries, something that could not be done in the past due to the lack of cross-country comparable data. In fact, our empirical analysis, using data from the European Community Household Panel (ECHP), shows that migrants into the pre-enlargement European Union choose their destination on the basis, among other things, of the generosity of welfare.

The paper, then, moves on from this result to argue that, if it is true that differences in the generosity of welfare affect the distribution of migration flows, there is scope for claiming more harmonisation in welfare policies within the Union. A first step in this direction would be the 
creation of a European-wide safety net: a last resort income benefit that would be paid to any resident in the Union whose income, adjusted by household size and purchasing power, falls below a certain threshold.

Almost all Member States already offer some sort of minimum income scheme - with the notable exceptions of Greece and Italy - but payments as well as access conditions differ a lot across countries. Not only may these differences affect negatively the distribution of the welfare costs of migration, but they could also dramatically reduce the potential benefits of migration in terms of labour reallocation.

Implementing such an harmonized system of income protection is not going to be easy: Member Countries will have to adjust their existing schemes to the new rule, some of them will have to increase benefits and others will have to reduce them, some countries might not be able to afford a system of this type (because of large income differences, high poverty rates, low levels of taxation, etc.). In other words, there will be losers and winners, and losers will tend to disagree with the proposal.

This paper estimates the overall cost of a European-wide minimum income scheme under various assumptions about its generosity and the way it will be financed. We also compute the distribution of costs and benefits across European Member States in order to understand which countries will benefit more from such a reform and where opposition is most likely to arise.

The paper is organised as follows. Section 2 briefly describes the data. Section 3 presents the empirical analysis of the correlation between welfare generosity and migration decisions. Section 4 presents and discusses the estimation of the costs and benefits of a European minimum income scheme. Section 5 concludes.

\section{The Data}

\subsection{The European Community Household Panel}

The European Community Household Panel is a panel dataset of households covering all the 15 pre-enlargement countries of the European Union. The ECHP started in 1994 and 8 waves of data have been released so far, covering the period from 1994 to 2001. Not all countries entered the 
survey at the same time and for three of them - Germany, Luxembourg and the United Kingdom - the original sample has been replaced after the first three waves with harmonised versions of household panels already been produced nationally: the German Socio-Economic Panel (GSOEP), the Luxembourg's Socio-Economic Panel (PSELL) and the British Household Panel Survey (BHPS). Identical sampling procedures are applied in all countries and individuals are administered the same set of questions, thus making the data highly comparable across countries.

Respondents to the ECHP questionnaire are also asked various questions about migration and citizenship. In what follows migrants are identified as those who either indicated to be citizens of a non EU-15 country or were born abroad and lived in a different country before arriving in the place of current residence.

We adopt this dual definition because it allows to cover the largest set of countries (e.g. there is no information on citizenship for Germany but migration trajectories are reported) and also because it is the one that performs better in comparison with official migration data from the OECD, as shown in Table $1^{1}$. There still exist discrepancies, which are sometimes large, between our estimates of the stock of foreign population and the official data but, considering that the ECHP is not explicitly designed for the study of migration and that the sample of migrants in some countries is relatively small, the overall performance of the ECHP on this issue can be considered satisfactory.

Another important piece of information available from the ECHP is the year of arrival in the current country of residence, which allows to match to each individual the economic conditions of all possible destination countries at the time the decision to migrate was taken. However, since data on welfare generosity and macroeconomic conditions are not easily available for the very past years, only migrants who arrived in the country of present residence in or after 1970 have been considered.

The sample has also been restricted to individuals who were aged between 15 and 55 at the time of arrival. Unfortunately, the data on welfare generosity are not available for Luxembourg and this country has been dropped from the sample used in section 3 (some figures for this country will still be produced in section 4$)$.

\footnotetext{
${ }^{1}$ In an earlier version, we defined migrants simply as those who were born abroad and had lived abroad before coming to the country of current residence. The empirical estimates produced using this alternative definition were qualitatively similar to the ones presented here. However, the dual definition used in the current version of this paper allows to identify a larger group of migrants and thus to produce more precise estimates. Moreover, it also replicates the official statistics more closely (see Table 1).
} 
Eventually, the empirical exercise of section 3 uses a sample of 3038 migrants from outside the pre-enlargement EU-15, distributed in 14 countries of the European Union according to Table 2. Summary statistics are also shown in Table 2, together with the distribution of the years of arrival for each destination country.

The data show that migrants usually move in their late twenties and that they are rather evenly distributed by gender with some countries, like Italy, where the presence of women is particularly high (probably because they cluster into female-dominated occupations, like housekeeping and nursing). The distribution of education is more varied with the Nordic and the Anglo-Saxon countries attracting the most educated migrants (with some exceptions like Greece and Spain).

For many countries the first nineties have been the years of most intense immigration but the data indicate a large variation in the sequence of migration waves across countries, resulting in a rather even distribution of arrivals for the entire Union.

It is worth mentioning here a couple of caveats of this sample. It is a known fact that some countries are often used as a port of entry (e.g. Italy, Spain, Greece, etc.) and the final destination of migration might not be the one observed in the data. The ECHP does not contain questions about the intention to leave the country in the future. We can only argue that most immigrants, who only transit in one country with the intention to move to another one, typically do that illegally and, even if they register, they remain in the port-of-entry country only for a very short period. Thus, they are very unlikely to be sampled in the ECHP. This also implies, however, that most illegal migrants will not be covered by our analysis.

\subsection{OECD Data-base on Benefit Entitlements and Replacement Rates}

Data on welfare generosity come from the OECD Data-base on Benefit Entitlements and Replacement Rates, which has been often used in the literature to describe the generosity as well as other characteristics of the welfare systems in the countries of the OECD.

In particular, this database measures the generosity of welfare by computing the ratio between income out of work - i.e. from welfare benefits - and income in work - i.e. some measure of the average wage. These figures, called replacement rates, are computed for several family types (single, couple with and without dependants), income levels (average earnings or 2/3 of the average earnings) and various durations of unemployment (from the first month up to the 60th month), as 
some benefits, like unemployment insurance, are paid only for a limited period of time.

The OECD produces these figures taking the average wage in the manufacturing sector (what is usually called the wage of the "average production worker" or APW) as a measure of earnings and, on the basis of each country's regulations, computes the amount of benefits a typical worker with that level of earnings is entitled to in case of unemployment. The calculation considers all cash benefits, i.e. unemployment benefits, housing benefits, family benefits and minimum income programmes.

The OECD Data-base on Benefit Entitlements and Replacement Rates exists in two versions. The first one contains gross replacement rates, i.e. computed without considering the taxation of benefits, which are indeed taxed in many OECD countries. This version of the database goes back as far as 1960. The second version includes taxes in the calculations but, unfortunately started only in 1995, thus, this paper uses gross benefits from the first version of the database ${ }^{2}$.

Since our interest lies in the separate identification of the effects of the wage and of welfare benefits on the destination of migrants, it has been necessary to reconstruct the level of the benefit from the replacement rate by multiplying the ratios by the APW earnings. Moreover, given that our identification strategy is based on the comparison of the combinations of wages, employment possibilities and welfare generosity across the destinations countries, the benefits have been adjusted by purchasing power.

Figure 1 shows the evolution over time and across countries of the measure of welfare generosity that will be used for the empirical analysis of section 3. These numbers are computed averaging the total amount of welfare benefits (in PPP-weighted current ECUs) over two income levels (APW and 2/3 of APW earnings), 3 family types (single, couple with dependent spouse, couple with working spouse) and several durations of unemployment (from 0 to 60 months).

The data in Figure 1 confirm what is a well known fact, that welfare institutions vary considerably across countries and offer a good deal of variation that can be exploited for econometric identification. Moreover, contrary to what has been sometimes argued, the generosity of welfare benefits changes noticeably also over time within countries, although this is not readily evident from the figure because the benefits are measured in current ECUs.

\footnotetext{
${ }^{2}$ The ECHP samples individuals in 1994 and then follows them over time. Hence, the very few migrants who arrived after 1995 are necessarily family reunions into sampled households.
} 


\section{Welfare generosity and the choice of migration: an em- pirical model}

In this section we borrow heavily from McFadden (1974) and Maddala (1983) to describe a structural model of the destination choice of migrants. We are implicitly assuming that the decision to migrate has already been taken and the only choice to be made concerns the country of destination. Meyer (2002) also uses a similar model and compares it with other empirical strategies that have been attempted in the literature.

Suppose that each individual $i$ is faced with $D$ alternative destination countries and utility obtainable from migrating into country $d$ is:

$$
U\left(\mathbf{x}_{i d}\right)=V\left(\mathbf{x}_{i d}\right)+\eta_{i d}
$$

where $V\left(\mathbf{x}_{i d}\right)$ is a deterministic function of a set of intrinsic characteristics of country $d$, possibly varying across individuals, $\mathbf{x}_{i d}$ (i.e. prevailing unemployment rate, average wages, etc.). $\eta_{i d}$ is a random component of utility for individual $i$ moving to country $d$. For simplicity, assume that $V\left(\mathbf{x}_{i d}\right)$ is linear: $V\left(\mathbf{x}_{i d}\right)=\mathbf{x}_{i d} \boldsymbol{\beta}$.

Individual $i$ will, therefore, choose destination $d$ if:

$$
U\left(\mathbf{x}_{i d}\right)>U\left(\mathbf{x}_{i k}\right) \text { for all } k \neq d
$$

Assuming that the random utility components $\eta_{i d}$ 's are all independently and identically distributed (over both $i$ and $d$ ) according to a type I extreme-value distribution ${ }^{3}$, the probability that individual $i$ chooses destination $d$ can be rewritten as $^{4}$ :

$$
\operatorname{Pr}\left\{V\left(\mathbf{x}_{i d}\right)+\eta_{i d} \geq V\left(\mathbf{x}_{i k}\right)+\eta_{i k} \quad \text { for all } k \neq d\right\}=\frac{e^{\mathbf{x}_{i d} \boldsymbol{\beta}}}{\sum_{k=1}^{D} e^{\mathbf{x}_{i k} \boldsymbol{\beta}}}=P_{i d}(\mathbf{x} \mid \boldsymbol{\beta})
$$

\footnotetext{
${ }^{3} \mathrm{~A}$ random variable $\eta_{i}$ has the type I extreme-value (or log Weibull) distribution if:

$$
\operatorname{Pr}\left\{\eta_{i} \leq \eta\right\}=\exp \left[-e^{-\eta}\right]
$$

${ }^{4}$ This specification satisfies the property of indipendence from irrelevant alternatives (see Maddala (1983)).
} 
Equation (3) clearly indicates that the identification in this model comes from comparing the same individual faced with different alternative destinations. In fact, since each individual $i$ is only observed taking one destination $d$, all individual characteristics that do not vary across countries (age, education, etc.) are collinear and cancel out in the specification of $P_{i d}$.

The log-likelihood function for a sample of $N$ migrants facing $D$ destinations can, then, be written as:

$$
L(\boldsymbol{\beta})=\sum_{i=1}^{N} \sum_{d=1}^{D} f_{i d} \log P_{i d}(\mathbf{x} \mid \boldsymbol{\beta})
$$

where $f_{i d}=1$ if individual $i$ chooses destination $d$ and zero otherwise.

The model described in equation (4) is estimated under various specifications of the utility function $U\left(\mathbf{x}_{i d}\right)$. Initially, we simply want to replicate the known result that employment possibilities and wages are the main determinants of the destination of migration. In order to test this hypothesis, the set of destination attributes, $\mathbf{x}_{i d}$, includes the unemployment rate and the average real wage in each destination country $d$ corresponding to the year in which individual $i$ settled into his/her country of current residence.

As additional controls, we always include a set of destination country dummies and 4 time period dummies for arrivals before 1980, between 1980 and 1985, between 1985 and 1990 and after 1990. These two sets of dummies are also interacted, thus allowing destination-specific effects (the strictness of migration laws, networks of migrants already present in the country, etc.) to change at discrete time intervals ${ }^{5}$.

Results are shown in the first column of Table 3 and indeed confirm that migrants tend to go into countries with lower unemployment rates and higher real wages. The second column of Table 3 repeats the same estimation adding to the set of explanatory variables the interactions between the log of the unemployment rate and of the wage with some individual characteristics, to check whether some groups are particularly sensitive to the conditions of the labour market.

The results indicate that the migration decisions of the more educated are less affected by unemployment and wages, perhaps because they generally have good changes of finding a job and their actual earnings are less correlated with the average. Those who migrate early in their

\footnotetext{
${ }^{5}$ Our results are robust to alternative specifications of the time effects and their interactions with the destination countries fixed-effects.
} 
lives (before 25 years old) also appear to attach less importance to the wage, probably because they see their experience in a different country also as an investment in human capital and are, therefore, willing to accept lower wages (compared to what they could earn in other destinations). Interestingly, there seems to be no detectable differences between men and women.

The third column of Table 3 introduces our measure of welfare benefits associated with the year of arrival in the destination country (in logs). The results show a positive and significant coefficient, indicating that, indeed, migrants are more likely to move into countries with more generous welfare benefits. This effect is reinforced when our measure of welfare generosity is interacted with the individual characteristics, as in column 4. Among the interaction coefficients, only the one with the gender dummy is significant, indicating that women are relatively less attracted by high-benefit countries ${ }^{6}$.

To get a first idea of the magnitude of these estimated effects, one could simply compare the coefficients of the log wage and the log benefit, which share the same unit of measurement. For example, from the figures in column 4 the effect of wages is more then 10 times larger than that of benefits.

More formally, one could look at the effect on migration into one country of changes in unemployment, wages and benefits either in the same or in the other countries. In fact, according to equation (3), the effect of a change in the $j-t h$ characteristic of country $d$ on the probability of migrating in country $d$ is equal to:

$$
\frac{\partial P_{i d}(\mathbf{x} \mid \boldsymbol{\beta})}{\partial x_{j i d}}=P_{i d}(\mathbf{x} \mid \boldsymbol{\beta})\left[1-P_{i d}(\mathbf{x} \mid \boldsymbol{\beta})\right] \beta_{j}
$$

while the effect on the same probability of a marginal change in the same $j-t h$ characteristic of another country $k \neq d$ is:

$$
\frac{\partial P_{i d}(\mathbf{x} \mid \boldsymbol{\beta})}{\partial x_{j i d}}=-P_{i d}(\mathbf{x} \mid \boldsymbol{\beta}) P_{k d}(\mathbf{x} \mid \boldsymbol{\beta}) \beta_{j}
$$

Using equation (5), Table 4 reports the direct effects of a change of one standard deviation in each of the three variables of main interest - the unemployment rate, the average wage and the

\footnotetext{
${ }^{6} \mathrm{~A}$ simple robustness check is presented in Table A1 in the Appendix, where all the estimations of Table 3 are repeated using public expenditure on unemployment related benefits as an alternative measure of welfare generosity.
} 
generosity of welfare - as implied by the estimates in column 4 of Table 3 and computed for a representative person (male, aged 25, with primary education and arrived in 1990). As indicated by the last two columns, the effect of a one-standard deviation change in the unemployment rate (which is a huge change of more than 3 percentage points) is only in a few countries comparable to a similar change in welfare benefits.

Perhaps, it is easier to interpret the ratio between the change in wages and benefits, since they share the same unit of measurement. The ratios in the last column of Table 4 show that increasing welfare benefits by one-standard deviation induces an increase in migration flows that is on average only $27 \%$ of what a similar change in wages would have generated. Only in Italy the size of the two effects is comparable but in this country benefits are extremely low and the simulated change of one-standard deviation leads to benefits more than 7 times higher.

The full matrix of both direct and cross- marginal effects computed for the reference person according to equations (5) and (6) is reported in Table A2 in the appendix. These numbers are useful to conduct the thought experiment reported in Table 5, which tries to relate these estimates to the initial issue of labour reallocation.

Suppose that there are only two possible destination countries, A and B, and that they are initially identical, with unemployment equal to $6 \%$ and welfare benefits of 5,000 euros per year (approximately the averages across the 14 countries used for the estimation). Migration flows will, then, be evenly distributed across the two countries, with the reference person migrating to any of them with a probability of $50 \%$. This is the benchmark situation described in the first panel of Table 5.

Suppose now - panel 2 in Table 5 - that the two countries are hit by an asymmetric shock to unemployment (assume, for simplicity, that wages are rigid) which goes up to $7 \%$ in country A and down to $5 \%$ in country B. The estimates of Table 3 predicts that this will generate a reduction of about 0.045 in the flow of migrants to country A and a symmetric increase for country B. This change in migration flows would, then, help to absorb the shock even if no native worker would move from A to B.

What would happen if benefits were changed too? Panel 3 computes the effect on the migration probabilities of a $20 \%$ increase in country A's benefits associated with an identical and simultaneous reduction in country $B$. The results indicate that the effect would be very similar that of the change 
in unemployment simulated in panel 2. In fact, when one computes the joint effect (panel 4) of these two asymmetric changes - to unemployment and benefits - one finds that changing benefits by $20 \%$ (a rather feasible reform) would almost completely offset the induced variations in migration flows generated by a notable, but not unreasonable, unemployment shock.

This is an important result. It is true that welfare generosity is a lot less important than labour market conditions in determining the location decisions of migrants, nevertheless its effect is large enough to dramatically reduce, and possibly completely offset, the potential benefits of migration in terms of labour reallocation, especially in countries with traditionally low geographical mobility.

In fact, while the direct effect of welfare benefits on migration choices is small, the cross-effects are sometimes surprisingly high (see Table A2).

\section{A European Minimum Income Programme}

\subsection{Basic set-up and costs}

The analysis conducted in the previous section indicates that differences in welfare generosity across countries may generate important distortions in the flows of migrants. A possible solution to this problem would be the harmonisation of welfare at the level of the Union.

A first step in this direction could be the creation of a European Minimum Income (MI), a scheme by which every household in the Union would be guaranteed a minimum income level, adjusted by the purchasing power of each country and equivalised for family type. This scheme may also substitute many of the existing welfare transfers currently being paid to low income households, such as housing or family benefits.

In this section we use the most recent wave of the $\mathrm{ECHP}^{7}$ to investigate the cost and the feasibility of a harmonised MI across the pre-enlargement EU-15 under various assumptions about its generosity and financing method.

We consider three different MI levels, defined on a monthly base at PPP-equivalent euros. As a benchmark we take a MI of 430.7 net monthly euros for a single person without children, a level that corresponds to the average of the minimum income schemes that were offered in 2000 by the

\footnotetext{
${ }^{7}$ The most recent wave of the ECHP contains data collected in 2001 and referring to incomes earned in 2000.
} 
countries of the Union ${ }^{8}$. Details on how this average has been calculated are provided in Table A3 in the Appendix. A lower - 215.35 monthly PPP euros, equal to 1/2 of the average - and a higher 861.4 monthly PPP euros, equal to twice the average - MI levels are also considered for comparison purposes. Table 6 converts these levels in 2000 euros for each country ${ }^{9}$.

For each MI level we, then, compute the number of eligible households (by country and in the EU-15 as a whole) and the cost of the programme. All households with total net incomes below the MI level are guaranteed a transfer equal to the difference between their actual net income and the MI. Formally, the total cost for country $d, T C_{d}$, is computed as:

$$
T C_{d}=\sum_{h=1}^{H_{d}} w_{h}\left(e_{h} M I-I_{h}\right) 1\left(I_{h}<e_{h} M I\right), \text { for each } d
$$

where 1(.) is an indicator function, equal to 1 when the condition between brackets is satisfied and 0 otherwise; $H_{d}$ is the total number households in the country; $M I$ is the monthly minimum income level for a single person (in PPP-euros); $e_{h}$ is an equivalence coefficient that transforms the MI level for a single person into the appropriate amount for family $h ; I_{h}$ is the total household monthly income (also in PPP-euros); $w_{h}$ is a household weight, adjusted to report the sample to the actual size of the population.

Summing over all the countries yields the overall cost of the programme for the entire Union:

$$
T C=\sum_{d=1}^{15} T C_{d}
$$

Household income is defined as the sum of incomes from all family members and all sources, excluding those social transfers that may be replaced by the MI, i.e. social assistance and housing allowance. This definition may be further restricted by excluding other transfers such as family benefits, invalidity benefits, etc. The choice of excluding only social assistance and housing allowances is due to the fact that in most countries all other categorical benefits coexists with minimum income programmes while housing and social assistance benefits are usually very much linked and administered together.

\footnotetext{
${ }^{8}$ Minimum income programmes exist in all the countries of the pre-enlargement EU-15, with the exception of Greece and Italy. In Italy, however, most towns have autonomously introduced a scheme of this type.

${ }^{9}$ The amounts in PPP euros are expressed in relation to a fictitious "average" European country with average cost of living.
} 
The equivalence scale we adopt is the one officially used by the OECD, which equals one for single adults and adds 0.7 for any additional adult and 0.5 for any additional child below 14 years-old.

Notice that we are neglecting any labour supply response. In principle, in fact, some households may react to the introduction of the new scheme by reducing their labour supply in order to become eligible for the programme. Taking this effect into consideration would require several additional pieces of information which are not readily available from the ECHP, the most important being gross incomes and labour supply elasticities. While gross incomes can be reasonably calculated using a net/gross factor at the household level (provided in the ECHP and which is used in the following subsection), the estimation of labour supply at the household level would be very problematic and goes beyond the scope of this paper.

Moreover, we believe that allowing for labour supply response would not change our results significantly for two reasons. First, the size of the response depends on the wage elasticity of labour supply, which we know from many empirical studies to be very low, especially in Europe (Blundell et al. (2000)). Second, most of the effect is likely to arise from changes in participation decisions rather than changes in the supply of hours of already employed workers. And, in our scheme, changes in the tax-benefit position of households around the participation margin are very limited because only households with net disposable incomes exceeding the MI threshold by at least $20 \%$ are subject to higher (or lower) taxation (see the following subsection).

Overall, the inclusion of labour supply responses in this analysis would require a number of ad hoc assumptions that will make the results questionable. For these reasons we prefer to keep things simple and present results from a static analysis.

Figure 2 shows the number of eligible households and the related annual costs for the three MI levels that we consider for the entire EU-15. These figures are plotted in percentage terms relative to the total number of households in the EU-15 and to the 2000 expenditure for housing and social assistance benefits, respectively. The data labels in the figure, instead, refer to the absolute numbers of recipient households and the absolute cost of the scheme.

At the lowest MI level, about 2.8 millions households (corresponding to about $1.8 \%$ of all EU-15 households) receive a transfer from the system with an aggregate cost of approximately 5.4 billions of euros (corresponding to $14 \%$ of current expenditure). These numbers increase rapidly as the MI level approaches the mean of the income distribution. With a minimum income equal to the 
European average of 430.7 PPP-euros some 10 millions households (corresponding to about $6.3 \%$ of all EU-15 households) would receive a transfer, generating a total expenditure of approximately 30 billions of euros (equal to about $74 \%$ of current expenditure). Finally, when we allow for an overly generous MI at twice the average, we get a total of 47.4 million recipient households (more than one third of all the households in the EU-15) facing an aggregate cost of over 250 billions of euros (more than 7 times what is currently spent).

Table 7 describes the distribution of recipients by country. As one could easily guess the poorest countries of the Union are the ones with the largest share of recipients. With a MI equal to the average $430.7 \mathrm{PPP}$-euros, more than $20 \%$ of households receive a transfer from the programme in Greece and Portugal. This figure goes down to $11 \%$ in Spain, $8 \%$ in Italy and so on. To give an idea of the actual amount of the transfer, the rightmost panel of Table 7 reports the average transfer per household in country euros.

Table 8 describes the distribution of costs by country in relation to what is currently spent for those welfare programmes that are likely to be replaced by the proposed European minimum income, i.e. social assistance and housing allowances. The figures in Table 8 highlight the large variety of welfare arrangements across the 15 countries of the pre-enlargement Union. The cost of a MI equal to our benchmark level of 430.7 PPP-euros, ranges from a mere $14 \%$ of current expenditure for similar schemes in Denmark (a country which is famous for the generosity of its welfare state) to more than 17 times the amount that Greece devoted to housing and social assistance benefits in 2000 .

These numbers indicate that the feasibility of a harmonised MI programme crucially depends on how it will be financed, an issue that is discussed in the following subsection.

\subsection{Financing}

We consider two possible scenarios for the financing of this hypothetical European minimum income. In the first case, which we label autarky, each country collects domestically, through a proportional top-up on the average tax rate, the revenue to finance the new scheme for its residents. Notice that in many countries the cost of the new MI is lower than what is currently spent for the programmes (housing and social protection) replaced by the MI in the current exercise and therefore taxes will be reduced. 
The alternative method, labelled centralised, is one in which the programme is financed through a proportional top-up tax identical for all households regardless of their country of residence. The structure of the top-up tax maintains the degree of progressivity of the tax system at the European level (or within countries in the autarky case).

While autarky generates redistribution of resources only within countries, in the centralised system rich countries pay more into the new scheme than they receive, generating a considerable redistribution of resources also across countries.

These two methods share the common feature that additional taxes will be levied only on those households whose income exceeds the MI threshold by at least 20\%. This ensures that the marginal tax rates around the MI threshold are not excessively high and discourage employment. More complicated mechanisms could be envisaged for this particular purpose, for example a gradual withdrawal of the benefit as household income increases ${ }^{10}$.

In autarky, then, taxes will be increased (or decreases) by the same factor $\alpha_{d}$ for all households in country $d$ in such a way to cover the additional (or lower) tax revenue necessary to finance the new programme for the residents in country $d . \alpha_{d}$ is computed in order to guarantee that the increase in taxes covers the additional revenue required to finance the MI, as stated in the following equation:

$$
\underbrace{\left[\left(1+\alpha_{d}\right) \sum_{h=1}^{H_{d}} w_{h} t_{h} Y_{h}^{1} 1\left(I_{h}>1.2 \cdot e_{h} \cdot M I\right)\right]}_{\text {total revenue after-reform }}-\underbrace{\left[\sum_{h=1}^{H_{d}} w_{h} t_{h} Y_{h}^{0}\right]}_{\text {total revenue pre reform }}=\underbrace{T C_{d}-S A_{d}}_{\text {additional revenue required }}
$$

where $t_{h}$ is the average tax rate for family $h, Y_{h}$ is gross total income for household $h$ and $S A_{d}$ is current (2000) expenditure for social assistance and housing benefits. All other symbols have been described above. The superscripts 0 and 1 on $Y_{h}$ indicate that after the reform some sources of income have been eliminated. In fact, the pre-reform gross income, $Y_{h}^{0}$, includes also social assistance and housing benefits, while these are excluded from $Y_{h}^{1}$, the post-reform gross income.

We compute gross incomes and the average tax rates using the net-to-gross factor provided in the ECHP. This variable is only available at the level of the household and allows to reconstruct, with some approximation, total household income from total net income and, consequently, to recover

\footnotetext{
${ }^{10}$ The distribution of winners and losers is, however, remarkably stable to changes in this exemption mechanism.
} 
the average tax rate. Unfortunately, this information is not available for Luxembourg and Sweden which have been excluded from these calculations.

From equation (9) it is immediate to derive an expression for $\alpha_{d}$ :

$$
\alpha_{d}=\frac{\left(T C_{d}-S A_{d}\right)+\sum_{h=1}^{H_{d}} w_{h} t_{h} Y_{h}^{0}}{\sum_{h=1}^{H_{d}} w_{h} t_{h} Y_{h}^{1} 1\left(I_{h d}>1.2 \cdot e_{h d} \cdot M I\right)}-1
$$

The values of $\alpha_{d}$ for each country are reported in Table A4 in the Appendix, while the upper panel of Table 9 describes the average increase (or reduction) in taxes and benefits in each country under autarky.

In the benchmark case of an MI equal to 430.7 PPP-euros, the Mediterranean countries (Greece, Italy, Portugal and Spain) and Ireland experience an increase in average benefits while in all the other countries benefits are reduced.

Normally, increases in average benefits are associated with higher taxes and vice versa. However, in some countries (Austria, Belgium, Germany and the Netherlands) the introduction of the MI leads to lower average benefits and higher taxes. In fact, spreading the cost of the new programme only on households with incomes exceeding the threshold by at least $20 \%$ reduces the tax base and requires higher average rates even when benefits are lowered.

The alternative scenario, i.e. the centralised system, is based on the same principle but operates at the level of the entire European Union (which, with the exclusion of Luxembourg and Sweden, is now a EU-13). In practice, in this scenario all member states would transfer to a central body what they are currently spending for housing and social assistance benefits. This fictitious central administration would, then, use these resources to pay MI transfers to all households who meet the eligibility criteria and charge additional taxes, through a common proportional increase in the average tax rate, should additional resources be needed. If total current expenditure is, instead, in excess of the cost of the MI, taxes would be reduced via the same system.

Hence, there is now a unique $\alpha$ applied to all households in the EU-13, regardless of their country of residence:

$$
\alpha=\frac{(T C-S A)+\sum_{h=1}^{H} w_{h} t_{h} Y_{h}^{0}}{\sum_{h=1}^{H} w_{h} t_{h} Y_{h}^{1} 1\left(I_{h}>1.2 \cdot e_{h} \cdot M I\right)}-1
$$

where $H$ is the total number of households in the entire Union (i.e. $H=\sum_{d} H_{d}$ ), $S A=\sum_{d} S A_{d}$ is the sum of current expenditure for housing and social assistance benefits in all the 13 countries 
considered and all the other symbols have the usual meaning.

The values of $\alpha$ for the three levels of the MI are reported in the bottom row of Table A4 in the Appendix. In the benchmark case, financing the new programme requires a small increase in average tax rates of about $2.7 \%$. The same number goes up to $33.8 \%$ for the most generous MI of 861.4 PPP-euros, while the lower MI level allows to reduce taxes by $1.4 \%$.

The bottom panel of Table 9 shows the distribution of average increases (or reductions) in taxes and benefits in each country under a centrally administered MI. While changes in benefits are identical to the autarky case reported in the upper panel, taxes are more equally spread across countries. Eventually, in the benchmark case only the Mediterranean countries (Greece, Italy, Portugal and Spain) receive more than they pay into the system.

\subsection{Voting over a European minimum income}

In order to understand whether such a programme will ever be politically feasible, in this section we try to count voters who will benefit from a hypothetical reform that replaces current housing and social assistance benefits with a minimum income scheme. Discussing the political economics of this policy change goes far beyond the scope of this paper and this section provides a mere headcount of winners and losers, abstracting from preferences over redistribution as well as from any other non-financial considerations.

By comparing changes in benefits and changes in taxes for each household, it is possible to identify whether each household would benefit or loose from the reform. Then, the number of voters who may favour the reform is computed by counting all individuals living in winning households who are above the voting age (18 years old in all the 13 countries considered here). The results of this simple exercise are reported in Figure 3.

Let us discuss the benchmark case first. Under autarky, only in 4 countries (France, United Kingdom, Denmark and Finland) there is a majority of voters who benefit from the reform. In these countries, in fact, an MI at 430.7 PPP-euros amounts to a substantial reduction in benefits and is therefore associated with lower taxes (see Table A4). In other words, these majorities arise from the many persons who will pay lower taxes at the expenses of few poor households who will receive lower benefits.

With a centralised system, even these 4 majorities are lost. In fact, in this case, the overall 
cost of the programme is spread equally across all member countries, thus also rich households in France, United Kingdom, Denmark and Finland will end up paying higher taxes.

The highest MI level, on the contrary, will have a potential majority of supporters only in the poorest countries of the Union, i.e. Greece and Portugal. In this case, in fact, the benefit is so high compared to the distribution of incomes that very many households will receive it at the expenses of a few very rich individuals who will pay very high taxes to finance it.

Notice that in this case the distribution of winners is unchanged, regardless of whether the scheme is financed locally or centrally. With benefits this high, in fact, taxes have to be increased in all countries. All tax-payers are losers and all benefit recipients are winners. In a centralised system, losers in rich countries will simply loose more.

Finally, the solution that seems to attract most potential support is the lowest MI. In this case, in fact, the reform generates reductions in social transfers in almost all countries (apart from the Mediterranean ones) and is thus associated with substantial and widespread tax rebates (see Table A4). Only in Greece, Italy, Portugal and Spain, even an MI at 215.35 PPP-euros is more generous than current housing and social assistance transfers and, thus, requires higher taxes in autarky. Notice, in fact, that, when the lower MI is financed centrally, a majority in favour of the reform can be reached also in the Mediterranean countries.

\section{Conclusions}

The results of this paper suggest that the generosity of the welfare state may act as a migration magnet across the countries of the European Union. This finding supports the concerns expressed by many observers of a potential threat to the welfare state posed by the enlargement of the Union.

On the other hand, however, the same estimates indicate that the size of these welfare magnets is relatively low, compared to the role of labour market conditions, such as the unemployment rate and the level of wages.

The issue, then, is not whether migrants will flood into countries with generous welfare benefits, but to what extent the variation in the welfare institutions across the countries of the Union will generate distortions in the flows of migration. The empirical analysis conducted in the first part of this paper shows that these distortions can be large enough to reduce, and possibly completely 
offset, the potential benefits of acquiring a more mobile labour force. This is, in fact, one of the most important advantages that increased migration can offer to the countries of the preenlargement Union, an area where native workers traditionally move a lot less than, for example, North-Americans.

The second part of the paper explores the feasibility of one possible solution to this problem: the creation of a more harmonised welfare system across the Union through the introduction of a uniform minimum income programme. Under various assumptions about the generosity and the method of financing, we compute the costs and the benefits of such a scheme for each country of the pre-enlargement Union.

The results indicate that, for a minimum income set at the average of similar programmes adopted in the EU, the new system would cost about three quarters of what is currently spent on housing and social assistance benefits and, considering that a programme of this type could easily replace these benefits, its cost does not seem unbearable.

The distribution, rather than the level, of the costs is more likely to create obstacles to its actual implementation. Imposing a uniform minimum income to all countries and requiring each of them to autonomously finance its own payments does not seem to obtain a majority that would support such a reform (if voters care only about their incomes). To make the new system politically feasible a certain degree of redistribution might be required, with some countries receiving more than they pay. A minimum income at a lower-than-average level financed via a centralised system is likely to obtain support from a majority in each country as well as in the entire Union. Our estimates indicate that the most generous MI level than is politically feasible is in the order of approximately 320 PPP-euros for a single individual.

\section{References}

[1] Alvarez-Plata, Patricia, Herbert Brücker and Boriss Siliverstovs. 2003. Potential Migration from Central and Eastern Europe into the EU-15 - An Update. Report for European Commission, DG Employment and Social Affairs, Brussels.

[2] Bartel, Ann P. 1989. "Where Do the New U.S. Immigrants Live?" Journal of Labour Economics $7(4): 371-391$. 
[3] Blank, Rebecca M. 1988. "The Effect of Welfare and Wage Levels on the Location Decisions of Female-Headed Households." Journal of Urban Economics 24(2): 186-211.

[4] Blundell, Richard, and MaCurdy, Thomas E. 2000. "Labor Supply: A Review of Alternative Approaches." In Handbook of Labor Economics, vol. 3a, edited by Orley Ashenfelter and David Card, pp. 1560-1695. Amsterdam: North-Holland.

[5] Boeri, Tito, Gordon H. Hanson and Barry McCormick. 2002. Immigration Policy and the Welfare System. Oxford University Press.

[6] Boeri, Tito and Herbert Brücker. 2001. The Impact of Eastern Enlargement on Employment and Labour Markets in the EU Member States. Report for European Commission, DG Employment and Social Affairs, Brussels.

[7] Borjas, George. 1999. "Immigration and Welfare Magnets." Journal of Labour Economics 17(4): 607-637.

[8] Gelbach, Jonah B. 2004. "Migration, the Life Cycle, and State Benefits: How Low Is the Bottom?" Journal of Political Economy 112(5): 1091-1130.

[9] Gramlich, Edward M. and Deborah S. Laren. 1984. "Migration and Income Redistribution Responsibilities." Journal of Human Resources 19(4): 489-511.

[10] Enchautegui, Maria. 1997. "Welfare Payments and Other Economic Determinants of Female Migration." Journal of Labor Economics 15(3): 529-554.

[11] Kennan, John and James R. Walker. 2003. "The Effect of Expected Income on Individual Migration Decisions." Working Paper No. 9585. NBER.

[12] Kvist, Jon. 2004. "Does EU enlargement start a race to the bottom? Strategic interaction among EU member states in social policy." Journal of European Social Policy 14(3): 301-318.

[13] Levine, Phillip B. and David J. Zimmerman. 1999. "An Empirical Analysis of the Welfare Magnet Debate Using the NLSY." Journal of Population Economics 12(3): 391-409.

[14] MacFadden, Daniel. 1973. "The Measurement of Urban Travel Demand." Journal of Public Economics 3(4): 303-328. 
[15] Maddala G. S. 1983. "Limited Dependent and Qualitative Variables in Econometrics." Cambridge University Press.

[16] McKinnish, Terra. 2005. "Importing the Poor: Welfare Magnetism and Cross-Border Migration." Journal of Human Resources 40(1): 57-76.

[17] Meyer, Bruce D. 2000. "Do the Poor Move to Receive Higher Welfare Benefits?" Working paper no. 58. Northwestern University, Joint Center for Poverty Research Working Paper.

[18] OECD. 2001. Trends in International Migration. Paris.

[19] Razin, Assaf and Efraim Sadka. 2000. "Interactions between international migration and the welfare state." Working Paper no. 337. CESifo.

[20] Sinn, Hans-Werner. 2001. "EU Enlargement, Migration and Lessons from German Unification." Discussion Paper no. 2174. CEPR.

[21] Sinn, Hans-Werner. 2004a. "Europe faces a rise in welfare migration." Financial Times (July 13), p. 13.

[22] Sinn, Hans-Werner. 2004b. "EU Enlargement, Migration and the New Constitution." Working Paper no. 1367. CESifo. 
welfare benefit*
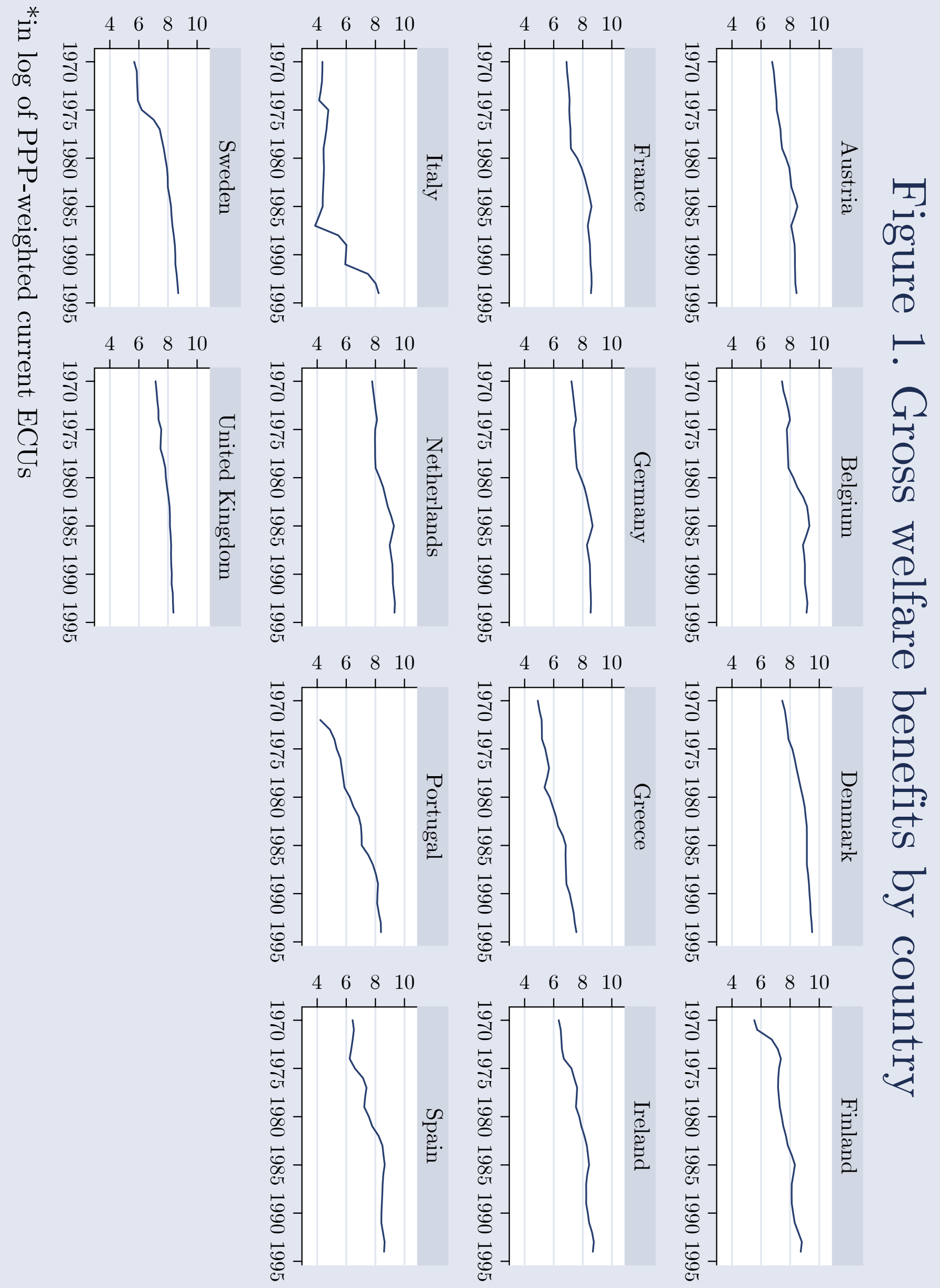


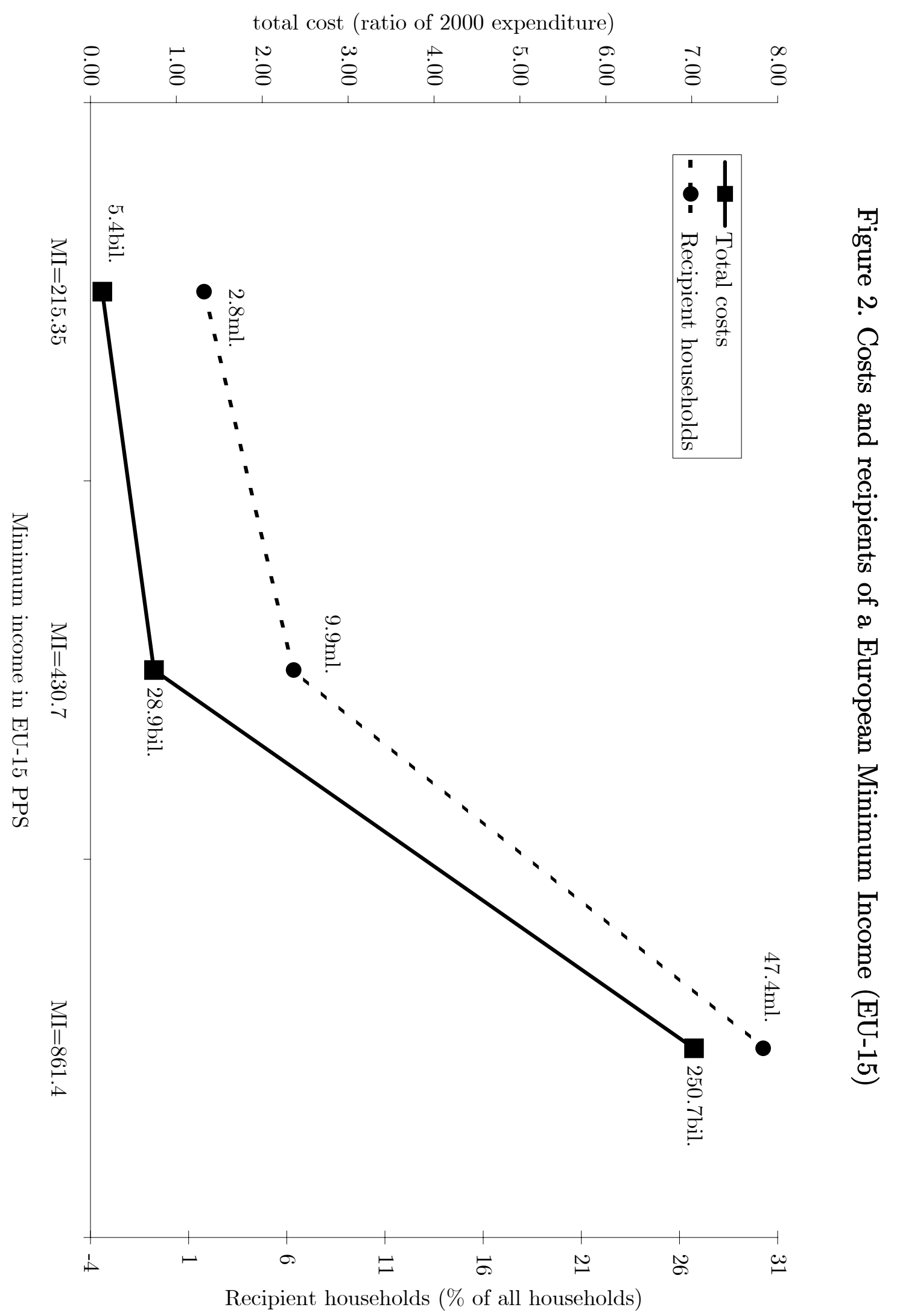




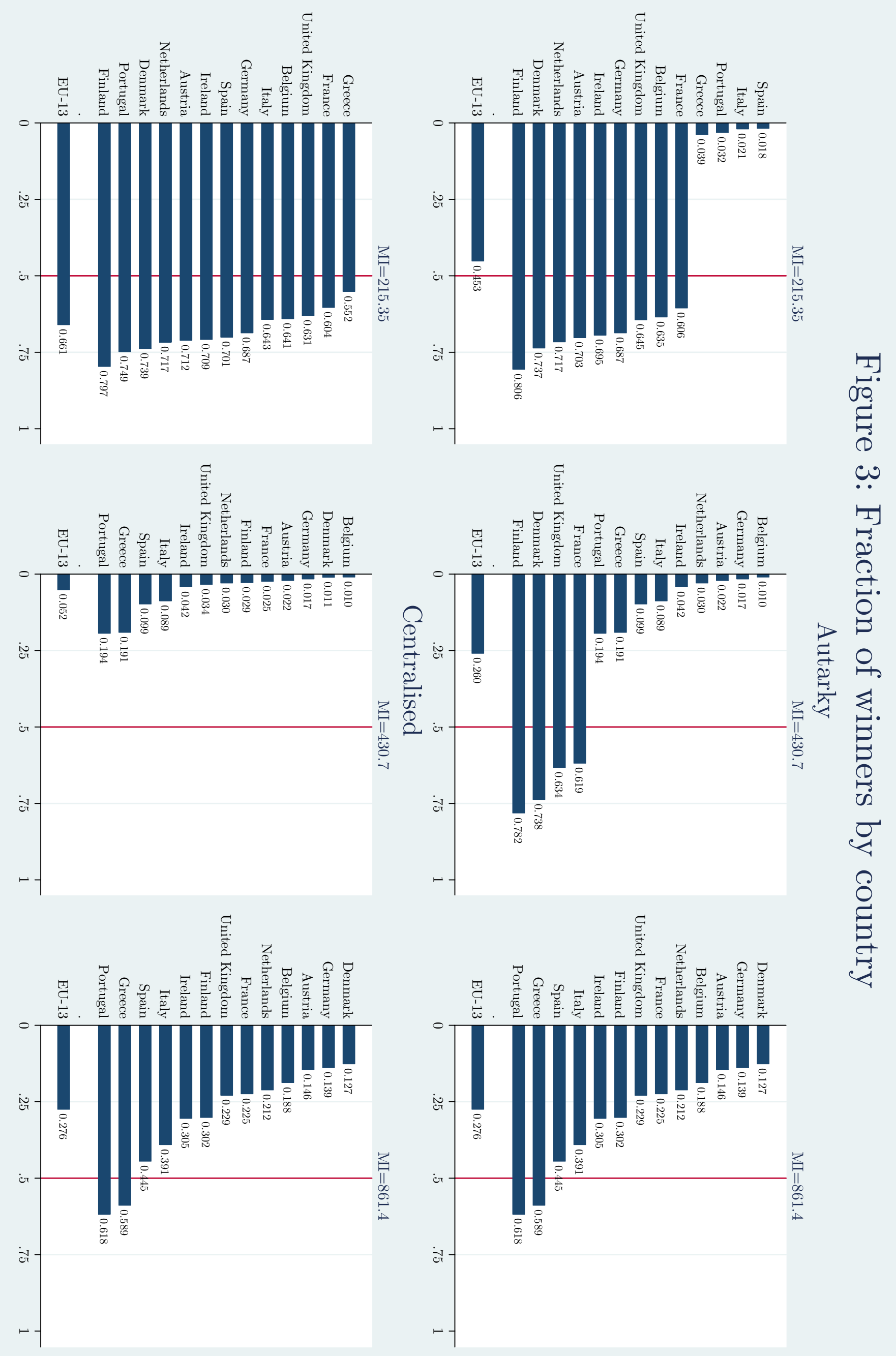


Table 1. Comparison of data sources

Stock of foregin population in 2001

\begin{tabular}{|c|c|c|}
\hline Country & $\mathrm{OECD}^{1}$ & $\mathrm{ECHP}^{2}$ \\
\hline Austria & 9.40 & 6.48 \\
\hline Belgium & 8.21 & 8.63 \\
\hline Denmark & 5.00 & 3.46 \\
\hline Finland & 1.90 & 3.51 \\
\hline France & .. & 7.52 \\
\hline Germany & 8.88 & 13.05 \\
\hline Greece & 7.00 & 4.41 \\
\hline Ireland & 3.90 & 3.73 \\
\hline Italy & 2.36 & 1.57 \\
\hline Luxembourg & 37.55 & 35.58 \\
\hline Netherlands & 4.26 & 1.61 \\
\hline Portugal & 2.17 & 2.47 \\
\hline Spain & 2.74 & 1.64 \\
\hline Sweden & 5.34 & 3.87 \\
\hline United Kingdom & 4.39 & 3.53 \\
\hline \multicolumn{3}{|c|}{$\begin{array}{l}\text { 1. Source: Trends in International Migration, OECD, } 2003 \\
\text { edition. Table A.1.5 }\end{array}$} \\
\hline \multicolumn{3}{|c|}{$\begin{array}{l}\text { 2. Foreign population defined as persons who declare to be } \\
\text { citizens of a foreign country or that they were born in a } \\
\text { foreign country (or both) }\end{array}$} \\
\hline
\end{tabular}


Table 2. Summary statistics

\begin{tabular}{|c|c|c|c|c|c|c|c|c|c|}
\hline \multirow[t]{2}{*}{$\begin{array}{l}\text { Country of } \\
\text { destination }\end{array}$} & \multirow[t]{2}{*}{$\begin{array}{c}\text { sample } \\
\text { size }\end{array}$} & \multirow{2}{*}{$\begin{array}{l}\text { age at } \\
\text { arrival }\end{array}$} & & $\begin{array}{l}\text { secondary } \\
\text { education }\end{array}$ & $\begin{array}{c}\text { tertiray } \\
\text { education }\end{array}$ & \multicolumn{4}{|c|}{$\begin{array}{l}\text { Distribution of year of arrival } \\
\text { (frequencies) }\end{array}$} \\
\hline & & & \multicolumn{3}{|c|}{ means (and stand.dev.) } & $<1975$ & $<1980$ & $<1985$ & $<1990$ \\
\hline Austria & 324 & $\begin{array}{c}27.9 \\
(8.89)\end{array}$ & $\begin{array}{l}0.54 \\
(0.50)\end{array}$ & $\begin{array}{c}0.46 \\
(0.50)\end{array}$ & $\begin{array}{c}0.17 \\
(0.38)\end{array}$ & 0.14 & 0.22 & 0.30 & 0.49 \\
\hline Belgium & 105 & $\begin{array}{l}25.9 \\
(8.07)\end{array}$ & $\begin{array}{l}0.49 \\
(0.50)\end{array}$ & $\begin{array}{c}0.31 \\
(0.47)\end{array}$ & $\begin{array}{c}0.36 \\
(0.48)\end{array}$ & 0.23 & 0.41 & 0.57 & 0.82 \\
\hline Denmark & 127 & $\begin{array}{l}26.5 \\
(8.66)\end{array}$ & $\begin{array}{l}0.56 \\
(0.50)\end{array}$ & $\begin{array}{c}0.28 \\
(0.45)\end{array}$ & $\begin{array}{c}0.28 \\
(0.45)\end{array}$ & 0.13 & 0.20 & 0.34 & 0.67 \\
\hline Finland & 184 & $\begin{array}{c}30.4 \\
(7.77)\end{array}$ & $\begin{array}{l}0.48 \\
(0.50)\end{array}$ & $\begin{array}{c}0.43 \\
(0.50)\end{array}$ & $\begin{array}{c}0.36 \\
(0.48)\end{array}$ & 0.10 & 0.19 & 0.41 & 0.61 \\
\hline France & 309 & $\begin{array}{c}27.2 \\
(9.07)\end{array}$ & $\begin{array}{l}0.56 \\
(0.50)\end{array}$ & $\begin{array}{c}0.13 \\
(0.34)\end{array}$ & $\begin{array}{c}0.24 \\
(0.43)\end{array}$ & 0.28 & 0.49 & 0.67 & 0.82 \\
\hline Germany & 950 & $\begin{array}{c}25.6 \\
(7.87)\end{array}$ & $\begin{array}{l}0.53 \\
(0.50)\end{array}$ & $\begin{array}{c}0.28 \\
(0.45)\end{array}$ & $\begin{array}{c}0.07 \\
(0.25)\end{array}$ & 0.45 & 0.59 & 0.68 & 0.81 \\
\hline Greece & 273 & $\begin{array}{l}28.2 \\
(8.64)\end{array}$ & $\begin{array}{l}0.61 \\
(0.49)\end{array}$ & $\begin{array}{c}0.40 \\
(0.49)\end{array}$ & $\begin{array}{c}0.33 \\
(0.47)\end{array}$ & 0.05 & 0.16 & 0.29 & 0.43 \\
\hline Ireland & 30 & $\begin{array}{c}30.8 \\
(7.41)\end{array}$ & $\begin{array}{l}0.40 \\
(0.50)\end{array}$ & $\begin{array}{c}0.40 \\
(0.50)\end{array}$ & $\begin{array}{c}0.40 \\
(0.50)\end{array}$ & 0.20 & 0.40 & 0.53 & 0.77 \\
\hline Italy & 85 & $\begin{array}{l}27.7 \\
(7.68)\end{array}$ & $\begin{array}{l}0.66 \\
(0.48)\end{array}$ & $\begin{array}{c}0.52 \\
(0.50)\end{array}$ & $\begin{array}{c}0.12 \\
(0.32)\end{array}$ & 0.09 & 0.25 & 0.41 & 0.66 \\
\hline Netherlands & 64 & $\begin{array}{c}26.2 \\
(8.08)\end{array}$ & $\begin{array}{l}0.59 \\
(0.50)\end{array}$ & $\begin{array}{c}0.08 \\
(0.27)\end{array}$ & $\begin{array}{c}0.05 \\
(0.21)\end{array}$ & 0.14 & 0.27 & 0.34 & 0.64 \\
\hline Portugal & 120 & $\begin{array}{c}29.9 \\
(11.33)\end{array}$ & $\begin{array}{c}0.56 \\
(0.50)\end{array}$ & $\begin{array}{c}0.28 \\
(0.45)\end{array}$ & $\begin{array}{c}0.18 \\
(0.38)\end{array}$ & 0.09 & 0.54 & 0.69 & 0.85 \\
\hline Spain & 114 & $\begin{array}{c}28.1 \\
(8.75)\end{array}$ & $\begin{array}{c}0.52 \\
(0.50)\end{array}$ & $\begin{array}{c}0.35 \\
(0.48)\end{array}$ & $\begin{array}{c}0.39 \\
(0.49)\end{array}$ & 0.10 & 0.22 & 0.39 & 0.67 \\
\hline Sweden & 139 & $\begin{array}{c}28.3 \\
(8.72)\end{array}$ & $\begin{array}{c}0.61 \\
(0.49)\end{array}$ & $\begin{array}{c}0.49 \\
(0.50)\end{array}$ & $\begin{array}{c}0.28 \\
(0.45)\end{array}$ & 0.03 & 0.10 & 0.18 & 0.37 \\
\hline United Kingdom & 214 & $\begin{array}{l}27.5 \\
(8.97)\end{array}$ & $\begin{array}{c}0.51 \\
(0.50)\end{array}$ & $\begin{array}{c}0.34 \\
(0.47)\end{array}$ & $\begin{array}{c}0.41 \\
(0.49)\end{array}$ & 0.19 & 0.34 & 0.47 & 0.66 \\
\hline Total & 3038 & $\begin{array}{c}27.2 \\
(8.63) \\
\end{array}$ & $\begin{array}{c}0.54 \\
(0.50) \\
\end{array}$ & $\begin{array}{c}0.33 \\
(0.47) \\
\end{array}$ & $\begin{array}{c}0.21 \\
(0.41) \\
\end{array}$ & 0.24 & 0.38 & 0.50 & 0.68 \\
\hline
\end{tabular}

Source: ECHP 1994-2001. 
Table 3. 14-countries conditional logit estimates for the destination of migration

Only migrants from outside the EU-15, arrived between 1970 and 1994

$[1] \quad[2] \quad[3] \quad[4]$

$\begin{array}{lcccc}(\log ) \text { unemployment rate [lURATE] } & -0.517^{* * *} & -0.600^{* * *} & -0.571^{* * *} & -0.538^{* * *} \\ & (0.093) & (0.108) & (0.108) & (0.109) \\ (\log ) \text { wage }[\mathrm{lWAGE}]^{2} & 4.449^{* * *} & 5.611^{* * *} & 5.649^{* * *} & 5.332^{* * *} \\ & (0.704) & (0.743) & (0.752) & (0.767) \\ (\log ) \text { welfare benefit }[\mathrm{B}]^{3} & & & 0.306^{* *} & 0.432^{* * *} \\ & & & (0.119) & (0.133)\end{array}$

Interaction terms: individual characteristics (at the time of arrival) with...

(Age at arrival-25)*[1URATE]

$\begin{array}{ccc}0.007 & 0.006 & 0.006 \\ (0.004) & (0.004) & (0.005) \\ -0.036 & -0.039 & -0.077 \\ (0.075) & (0.075) & (0.076) \\ 0.005 & -0.000 & -0.029 \\ (0.087) & (0.087) & (0.089) \\ 0.743^{* * *} & 0.732^{* * *} & 0.745^{* * *} \\ (0.107) & (0.107) & (0.108) \\ -0.070^{* * *} & -0.070^{* * *} & -0.070^{* * *} \\ (0.014) & (0.014) & (0.017) \\ -0.257 & -0.238 & 0.216 \\ (0.244) & (0.245) & (0.297) \\ -1.914^{* * *} & -1.896^{* * *} & -1.612^{* * *} \\ (0.290) & (0.292) & (0.350) \\ -1.785^{* * *} & -1.761^{* * *} & -1.983^{* * *} \\ (0.318) & (0.320) & (0.387)\end{array}$

Female*[1URATE]

Secondary education*[1URATE]

Tertiary education*[IURATE]

$0.743^{* * *}$

$0.732^{* * *}$

(Age at arrival-25)*[1WAGE]

$-0.070^{* * *}$

$-0.070 * * *$

$0.070^{* * *}$

Female*[1WAGE]

0.216

Secondary education*[1WAGE]

Tertiary education*[1WAGE]

$\begin{array}{ccc} & & 0.000 \\ & & (0.004) \\ & -0.175^{* * *} \\ & (0.064) \\ & -0.113 \\ & (0.072) \\ & & 0.093 \\ & & (0.084) \\ & & \\ & & 42058 \\ 42058 & 42058 & 3038 \\ 3038 & 3038 & -6477.38 \\ -6487.91 & -6484.48 & \end{array}$

(Age at arrival-25)*[B]

Female*[B]

Secondary education*[B]

Tertiary education*[B]

\begin{tabular}{lcccc} 
Observations & 42058 & 42058 & 42058 & 42058 \\
Individuals & 3038 & 3038 & 3038 & 3038 \\
Log-Likelihood & -6564.39 & -6487.91 & -6484.48 & -6477.38 \\
\hline
\end{tabular}

All specifications include a full set of destination country dummies, 4 5-year period dummies and the interactions between these two sets of dummies.

1. Source: OECD Economic Outlook. Values in percentage.

2. Annual compensation per employee in the private sector. Source: OECD Economic Outlook. All values are expressed in PPP/ECU.

3. Monthly benefit received a typical person aged 40 who has continuously worked and paid contributions since the age of 18 , averaged over a period of 60 months of non-employment, two earning levels (100\% and $33 \%$ of the earnings of the average production worker) and three family types (single, one-earner couple, twoearners couple). Source: OECD Data-base on Benefit Entitlements and Replacement Rates. All values are expressed in PPP/ECU.

Standard errors in parentheses

* significant at $10 \%$; ** significant at $5 \%$; *** significant at $1 \%$ 
Table 4. Effects of one-standard deviation increases for the reference person ${ }^{1}$ Effect of an increase of 1 standard deviation in:

\begin{tabular}{|c|c|c|c|c|c|}
\hline \multirow{2}{*}{ Country } & own unemp. rate & own wages & own benefits & \multicolumn{2}{|c|}{ own benefit effect } \\
\hline & {$[1]$} & {$[2]$} & {$[3]$} & {$[3] /[1]$} & {$[3] /[2]$} \\
\hline mean & 6.7 & 18163.9 & 4986.0 & & \\
\hline std.dev. & 3.1 & 3412.8 & 2993.7 & & \\
\hline Austria & -0.0358 & 0.1067 & 0.0277 & 0.77 & 0.26 \\
\hline Belgium & -0.0112 & 0.0427 & 0.0071 & 0.64 & 0.17 \\
\hline Denmark & -0.0123 & 0.0537 & 0.0064 & 0.52 & 0.12 \\
\hline Finland & -0.0268 & 0.0717 & 0.0187 & 0.70 & 0.26 \\
\hline France & -0.0114 & 0.0619 & 0.0143 & 1.25 & 0.23 \\
\hline Germany & -0.0539 & 0.1549 & 0.0387 & 0.72 & 0.25 \\
\hline Greece & -0.0111 & 0.0633 & 0.0300 & 2.71 & 0.47 \\
\hline Ireland & -0.0015 & 0.0105 & 0.0030 & 1.96 & 0.29 \\
\hline Italy & -0.0041 & 0.0229 & 0.0239 & 5.88 & 1.04 \\
\hline Netherlands & -0.0107 & 0.0346 & 0.0054 & 0.50 & 0.16 \\
\hline Portugal & -0.0039 & 0.0227 & 0.0040 & 1.01 & 0.17 \\
\hline Spain & -0.0040 & 0.0342 & 0.0069 & 1.71 & 0.20 \\
\hline Sweden & -0.0275 & 0.0506 & 0.0099 & 0.36 & 0.20 \\
\hline United Kingdom & -0.0173 & 0.0631 & 0.0187 & 1.08 & 0.30 \\
\hline Average & -0.0165 & 0.0567 & 0.0153 & 0.93 & 0.27 \\
\hline
\end{tabular}

1. Male, aged 25, primary education, arrived in 1990. 


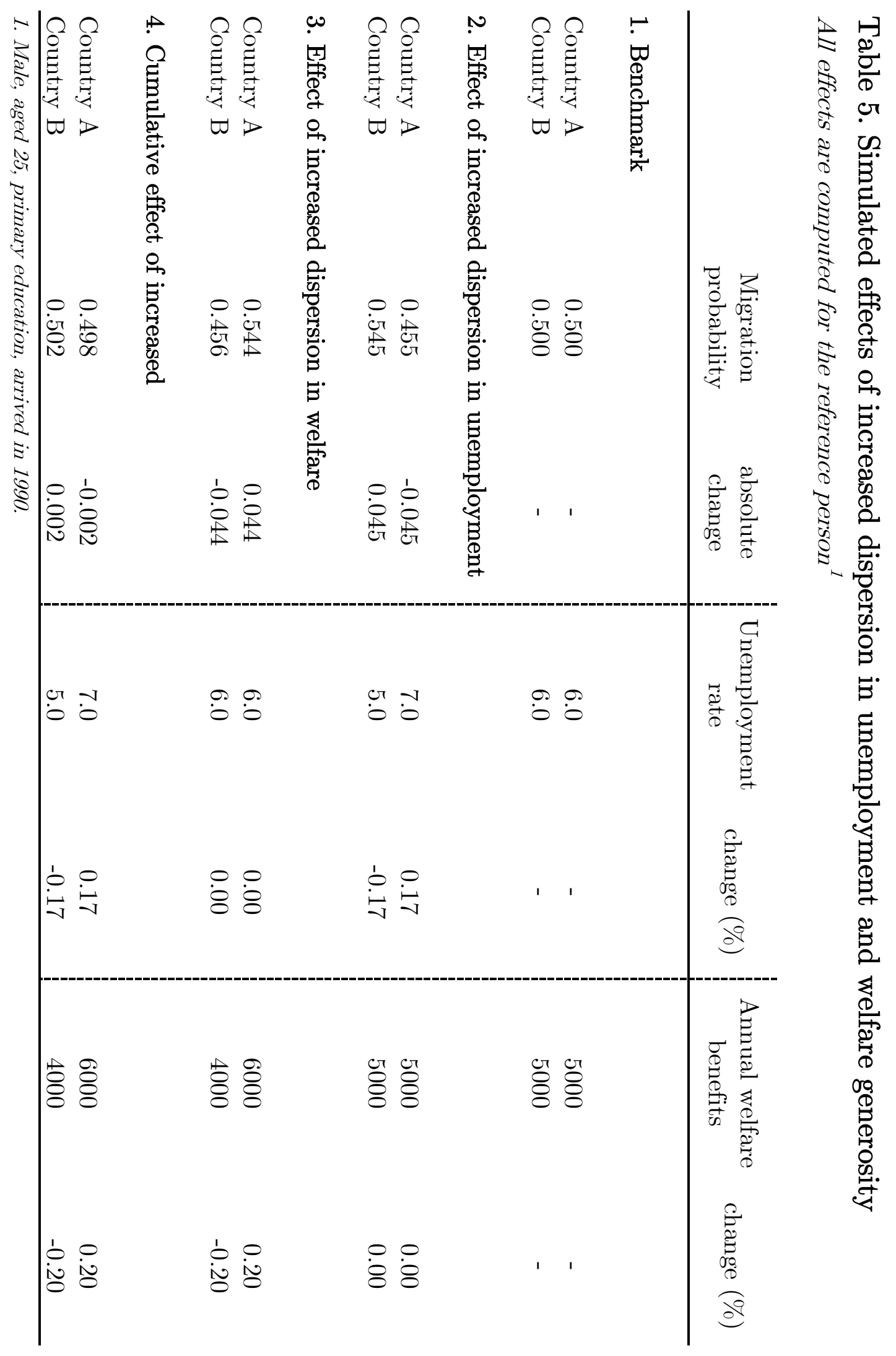


Table 6. Minimum Income amounts in country-euros

\begin{tabular}{lccc} 
Country & $\begin{array}{c}0.5 \times \text { Average } \\
\text { MI=215.35 }\end{array}$ & $\begin{array}{c}\text { Average } \\
\text { MI=430.7 }\end{array}$ & $\begin{array}{c}2 \times \text { Average } \\
\text { MI=861.4 }\end{array}$ \\
\hline Austria & & & \\
Belgium & 208.6 & 417.3 & 834.5 \\
Denmark & 215.6 & 431.1 & 862.3 \\
Finland & 261.2 & 522.5 & 1044.9 \\
France & 250.0 & 500.0 & 1000.1 \\
Germany & 219.4 & 438.9 & 877.8 \\
Greece & 214.5 & 429.0 & 858.0 \\
Ireland & 168.7 & 337.4 & 674.8 \\
Italy & 232.1 & 464.3 & 928.6 \\
Luxembourg & 190.8 & 381.5 & 763.0 \\
Netherlands & 207.7 & 415.3 & 830.6 \\
Portugal & 214.9 & 429.8 & 859.7 \\
Spain & 155.6 & 311.2 & 622.4 \\
Sweden & 178.7 & 357.4 & 714.8 \\
United Kingdom & 275.1 & 550.3 & 1100.6 \\
& 254.9 & 509.7 & 1019.4
\end{tabular}




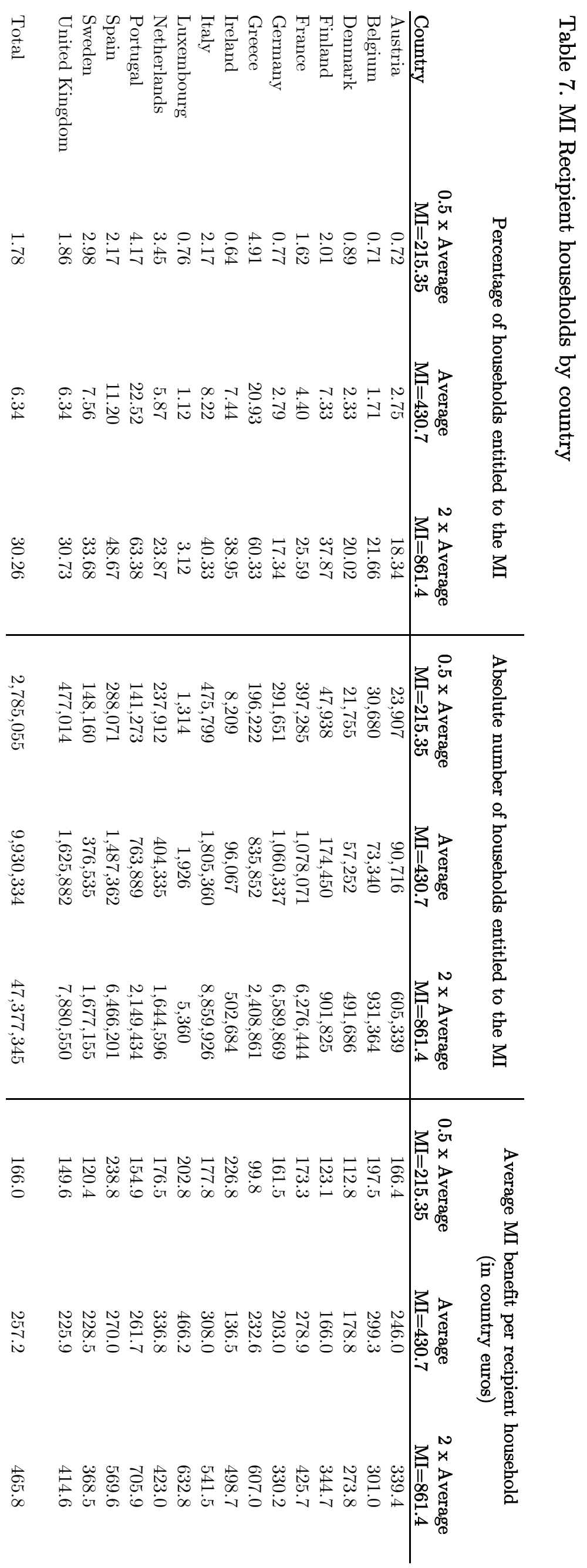




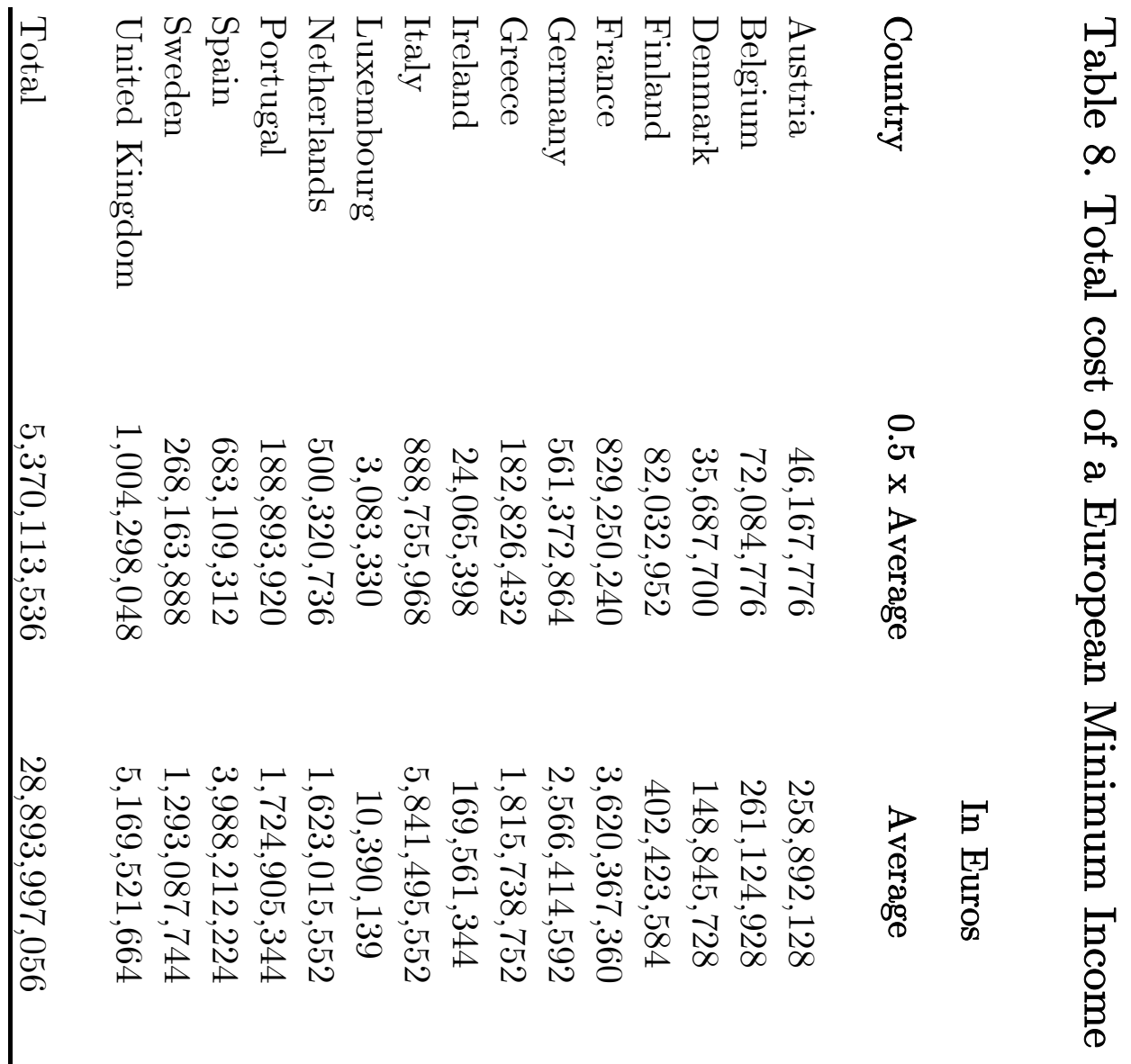

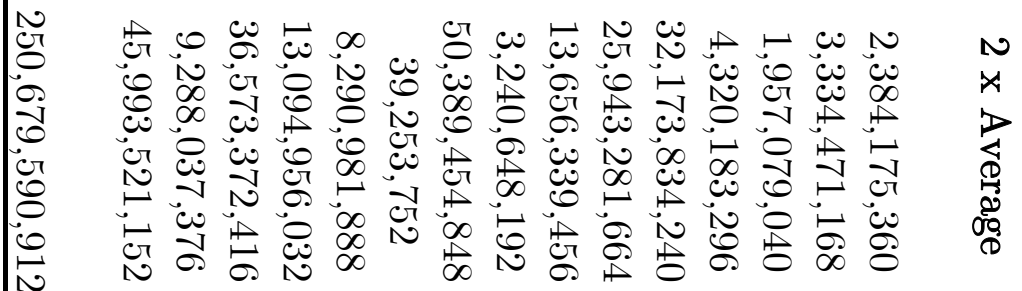

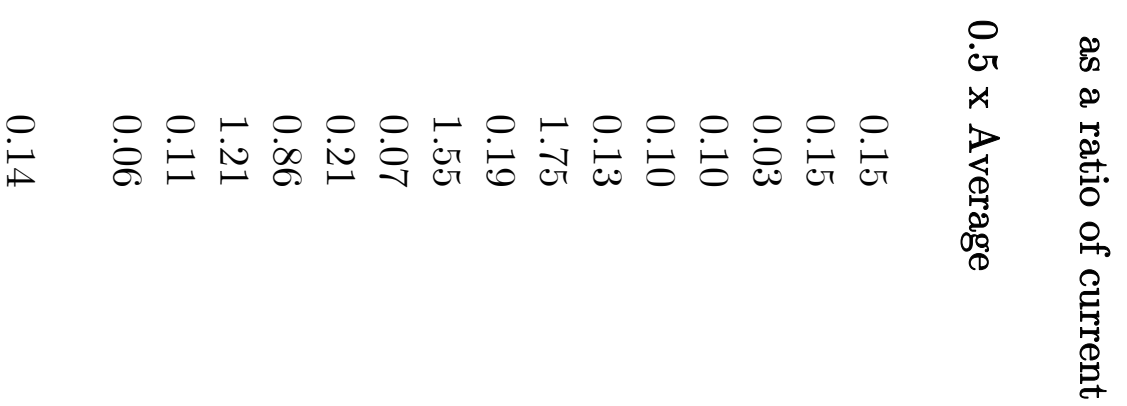

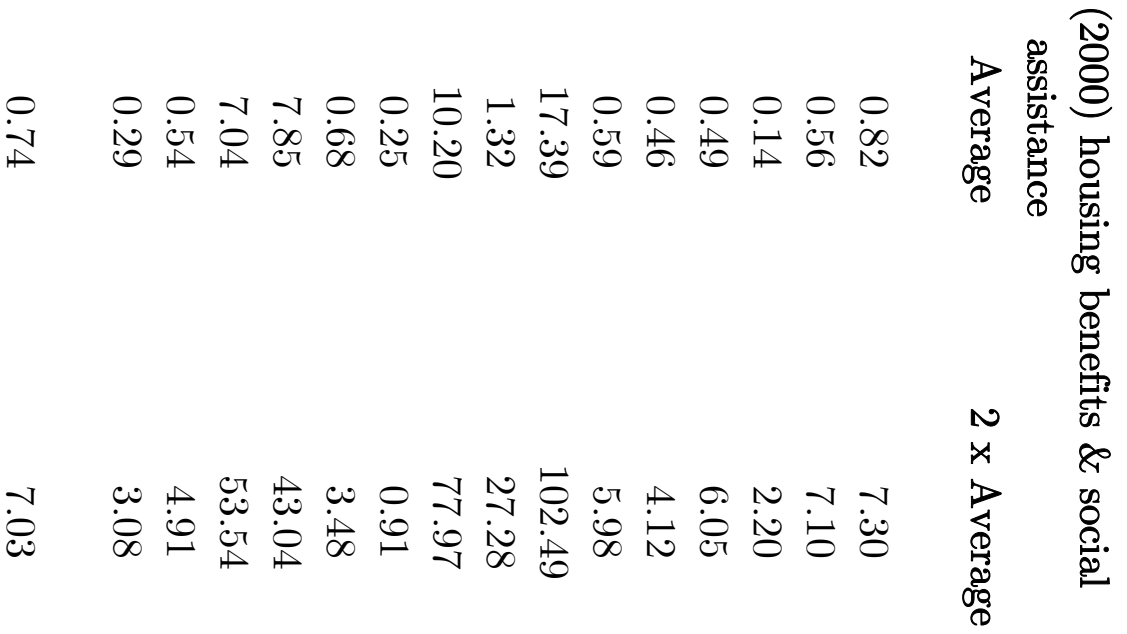




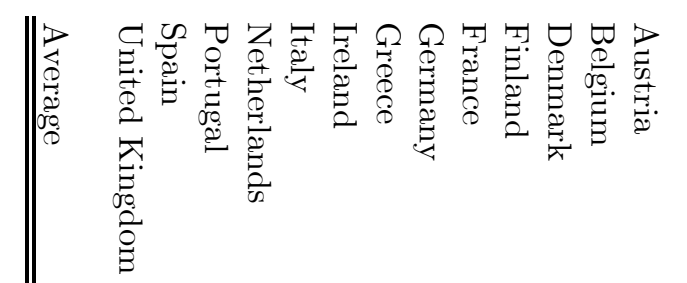

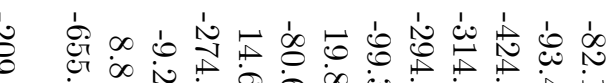

每

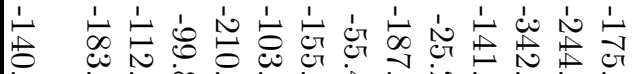

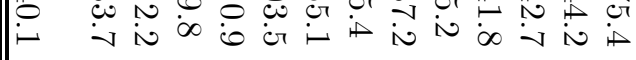

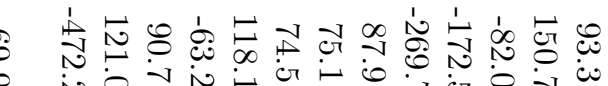

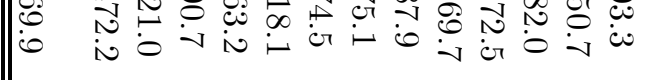

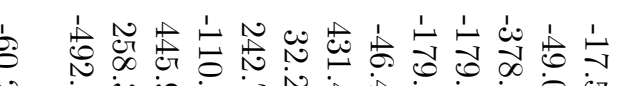

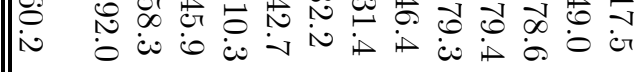

预

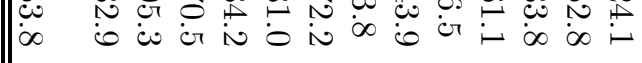

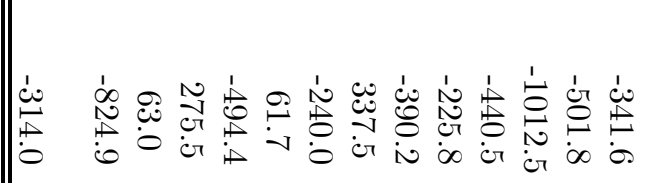

剀

ن

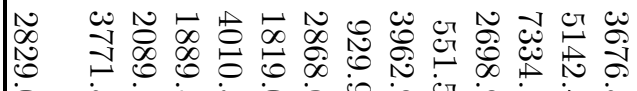

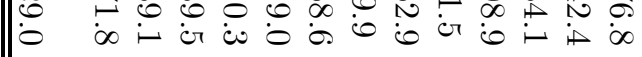

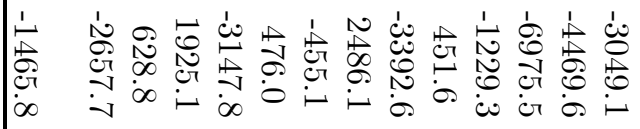

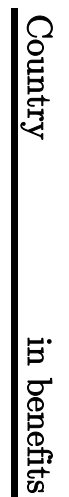
0 N 究

$\frac{\sqrt[0]{0}}{0^{+}}$

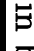

惫

象

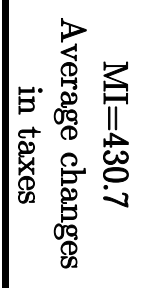

is

$\frac{\sqrt{0}}{0}$

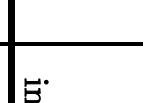

8

曋

蜼

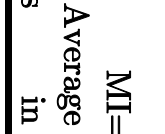

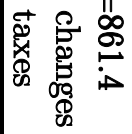

$\frac{e^{2}}{0}$

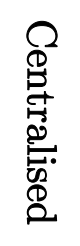

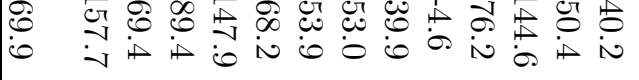

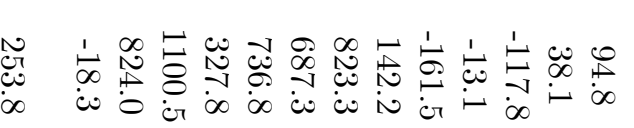

嵌

\begin{tabular}{|l|l|l|l}
\hline & \\
\hline
\end{tabular}

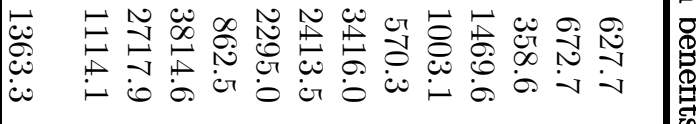

N

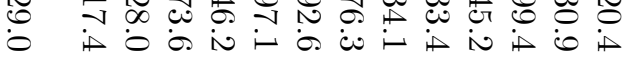

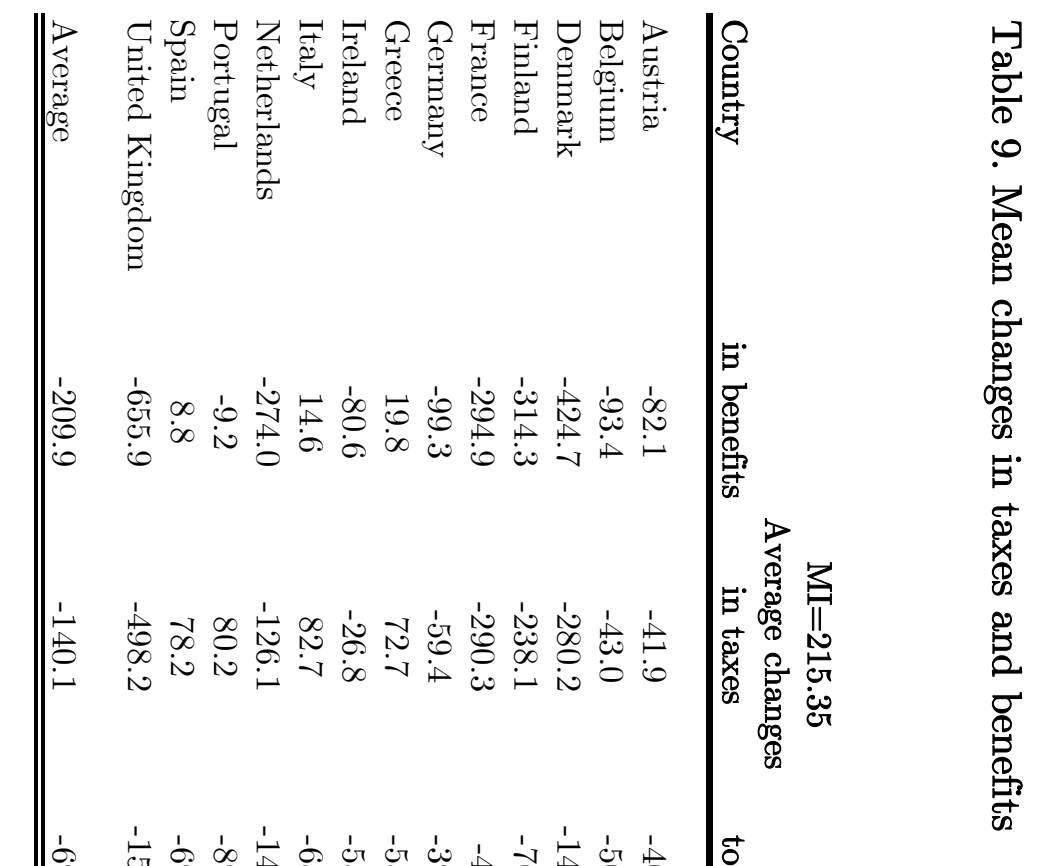

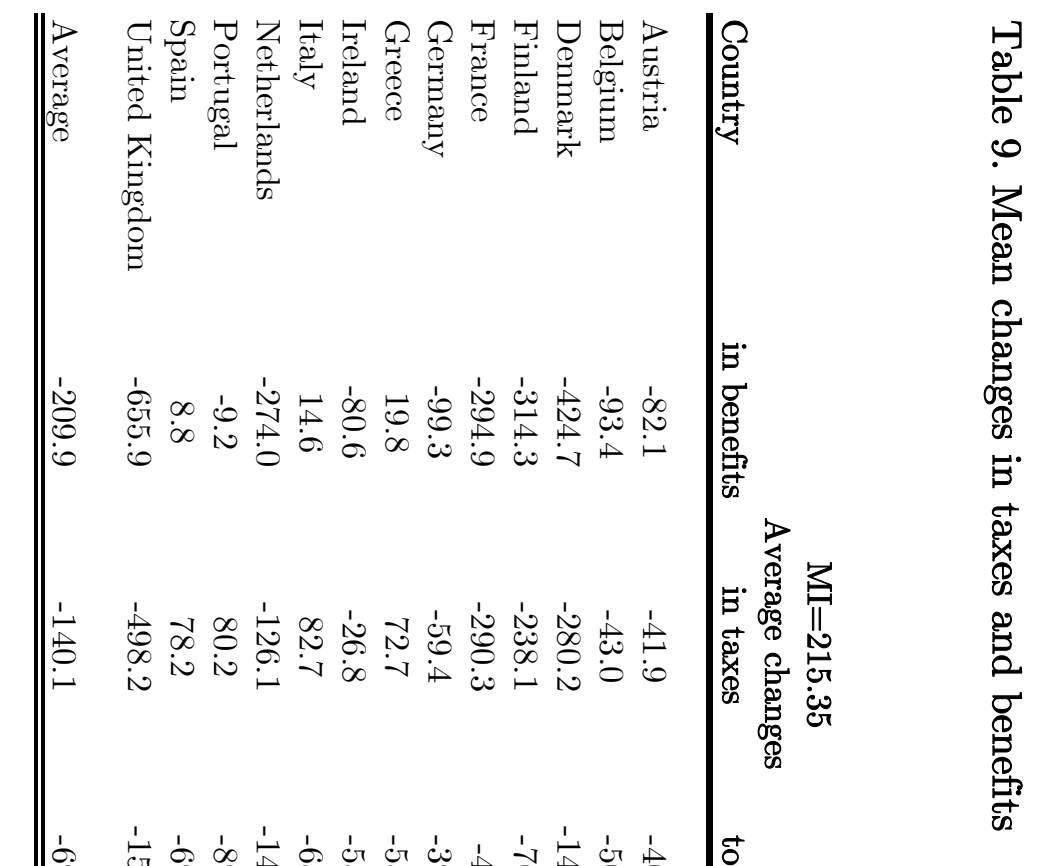

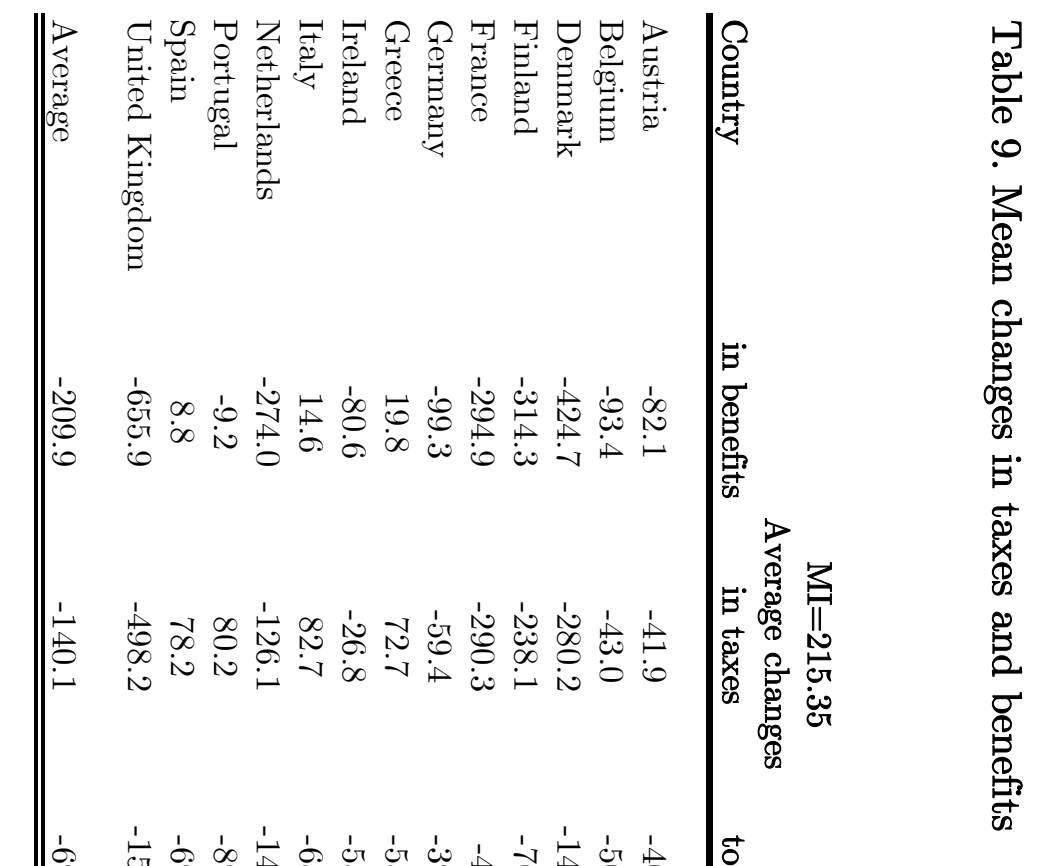

蛋

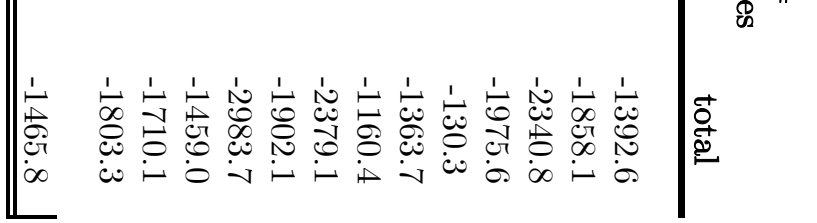


Only migrants from outside the EU-15, arrived between 1970 and 1994

\begin{tabular}{lccc} 
& {$[1]$} & {$[2]$} & {$[3]$} \\
\hline$(\log )$ unemployment rate [lURATE] & $-0.925^{* * *}$ & $-0.958^{* * *}$ & $-0.949^{* * *}$ \\
& $(0.137)$ & $(0.151)$ & $(0.152)$ \\
$(\log )$ wage [lWAGE] $]^{2}$ & 0.875 & $4.113^{* * *}$ & $4.374^{* * *}$ \\
& $(1.254)$ & $(1.340)$ & $(1.378)$ \\
Public expenditure on unemployment & $0.354^{* * *}$ & $0.363^{* * *}$ & $0.312^{* *}$ \\
related benefits (\% of GDP) [B] $]^{3}$ & $(0.134)$ & $(0.135)$ & $(0.157)$
\end{tabular}

Interaction terms: individual characteristics (at the time of arrival) with...

(Age at arrival-25)*[1URATE]

Female*[1URATE]

Secondary education*[1URATE]

Tertiary education*[IURATE]

(Age at arrival-25)*[1WAGE]

Female*[1WAGE]

Secondary education*[1WAGE]

Tertiary education*[lWAGE]

(Age at arrival-25)*[B]

Female*[B]

Secondary education*[B]

Tertiary education*[B]

$\begin{array}{cc}0.005 & 0.004 \\ (0.005) & (0.005) \\ -0.155^{* * *} & -0.163^{* * *} \\ (0.032) & (0.038) \\ 0.008 & 0.014 \\ (0.090) & (0.091) \\ -0.153 & -0.062 \\ (0.538) & (0.650) \\ -0.042 & -0.075 \\ (0.105) & (0.107) \\ 0.745^{* * *} & 0.739^{* * *} \\ (0.134) & (0.135) \\ -5.583^{* * *} & -6.305^{* * *} \\ (0.634) & (0.765) \\ -6.337^{* * *} & -6.483^{* * *} \\ (0.739) & (0.890)\end{array}$

0.002

$(0.006)$

$-0.027$

(0.093)

$0.187^{*}$

$(0.108)$

0.029

$(0.119)$

Observations

18882

1683

18882

18882

Individuals $-3140.257$

1683

1683

Log-Likelihood $-3053.4802$ $-3051.7642$

All specifications include a full set of destination country dummies, 4 5-year period dummies and the interactions between these two sets of dummies.

1. Source: OECD Economic Outlook. Values in percentage.

2. Annual compensation per employee in the private sector. Source: OECD Economic Outlook. All values are expressed in PPP/ECU.

3. Source: Comparative Welfare State Dataset (2004) by Evelyne Huber, Charles Ragin, John D. Stephens, David Brady, and Jason Beckfield based on various OECD data sources.

Standard errors in parentheses

* significant at $10 \% ; * *$ significant at $5 \% ; * * *$ significant at $1 \%$ 
Table A2. Cross-effects of one-standard deviation increases for the reference person ${ }^{1}$ (all effects are multiplied by 100)

Unemployment rate

\begin{tabular}{l|cccccccccccccc} 
& AUT & BEL & DEN & FIN & FRA & GER & GRC & IRL & ITA & NLD & PRT & ESP & SWE & UKG \\
\hline AUT & -3.577 & 0.162 & 0.180 & 0.398 & 0.169 & 0.989 & 0.161 & 0.021 & 0.057 & 0.154 & 0.054 & 0.057 & 0.396 & 0.257 \\
BEL & 0.234 & -1.117 & 0.074 & 0.164 & 0.070 & 0.408 & 0.066 & 0.009 & 0.024 & 0.064 & 0.022 & 0.024 & 0.164 & 0.106 \\
DEN & 0.280 & 0.080 & -1.226 & 0.197 & 0.084 & 0.489 & 0.080 & 0.011 & 0.028 & 0.076 & 0.027 & 0.028 & 0.196 & 0.127 \\
FIN & 0.327 & 0.093 & 0.104 & -2.680 & 0.098 & 0.570 & 0.093 & 0.012 & 0.033 & 0.089 & 0.031 & 0.033 & 0.229 & 0.148 \\
FRA & 0.316 & 0.090 & 0.100 & 0.222 & -1.142 & 0.551 & 0.090 & 0.012 & 0.032 & 0.086 & 0.030 & 0.032 & 0.221 & 0.144 \\
GER & 1.055 & 0.301 & 0.335 & 0.741 & 0.315 & -5.392 & 0.300 & 0.040 & 0.106 & 0.288 & 0.101 & 0.106 & 0.739 & 0.479 \\
GRC & 0.246 & 0.070 & 0.078 & 0.173 & 0.074 & 0.430 & -1.107 & 0.009 & 0.025 & 0.067 & 0.024 & 0.025 & 0.173 & 0.112 \\
IRL & 0.055 & 0.016 & 0.017 & 0.039 & 0.016 & 0.096 & 0.016 & -0.154 & 0.006 & 0.015 & 0.005 & 0.006 & 0.038 & 0.025 \\
ITA & 0.109 & 0.031 & 0.035 & 0.077 & 0.033 & 0.191 & 0.031 & 0.004 & -0.406 & 0.030 & 0.010 & 0.011 & 0.076 & 0.050 \\
NLD & 0.207 & 0.059 & 0.066 & 0.145 & 0.062 & 0.361 & 0.059 & 0.008 & 0.021 & -1.074 & 0.020 & 0.021 & 0.145 & 0.094 \\
PRT & 0.062 & 0.018 & 0.020 & 0.043 & 0.018 & 0.108 & 0.018 & 0.002 & 0.006 & 0.017 & -0.392 & 0.006 & 0.043 & 0.028 \\
ESP & 0.135 & 0.039 & 0.043 & 0.095 & 0.040 & 0.236 & 0.038 & 0.005 & 0.014 & 0.037 & 0.013 & -0.403 & 0.095 & 0.061 \\
SWE & 0.210 & 0.060 & 0.067 & 0.148 & 0.063 & 0.367 & 0.060 & 0.008 & 0.021 & 0.057 & 0.020 & 0.021 & -2.753 & 0.096 \\
UKG & 0.341 & 0.097 & 0.108 & 0.239 & 0.102 & 0.595 & 0.097 & 0.013 & 0.034 & 0.093 & 0.033 & 0.034 & 0.238 & -1.728 \\
\hline
\end{tabular}

Average wages

\begin{tabular}{|c|c|c|c|c|c|c|c|c|c|c|c|c|c|c|}
\hline & & EL & EN & IN & $R A$ & ER & $\mathrm{RC}$ & $2 \mathrm{~L}$ & A & LD & RT & ESP & $\mathrm{E}$ & $G$ \\
\hline$\overline{\mathrm{AUT}}$ & 675 & 618 & 787 & 064 & -0.916 & 840 & 919 & 145 & 321 & 498 & -0.315 & .483 & .729 & .939 \\
\hline BEL & .698 & 4.266 & .325 & .439 & -0.379 & -1.173 & -0.380 & .060 & .133 & .206 & -0.130 & -0.200 & .301 & 8 \\
\hline DEN & 836 & -0.306 & 5.368 & -0.526 & -0.453 & -1.405 & -0.455 & -0.072 & -0.159 & -0.247 & -0.156 & -0.239 & -0.360 & -0.465 \\
\hline FIN & .975 & -0.356 & -0.454 & 7.168 & -0.529 & -1.638 & -0.530 & -0.084 & -0.185 & -0.287 & -0.182 & -0.279 & -0.420 & -0.542 \\
\hline $2 \mathrm{~A}$ & 43 & 345 & .439 & .593 & 6.193 & -1.584 & -0.513 & -0.081 & -0.179 & -0.278 & -0.176 & -0.269 & -0.406 & 0.524 \\
\hline $\mathrm{ER}$ & 149 & 51 & 466 & 981 & .707 & 15.488 & .713 & .270 & 98 & 28 & -0.588 & 00 & 57 & 50 \\
\hline$R C$ & 735 & 269 & 342 & .463 & -0.399 & -1.236 & 6.326 & -0.063 & 10 & .217 & -0 . & -0.210 & 17 & .409 \\
\hline $\mathrm{L}$ & .164 & -0.060 & -0.076 & -0.103 & -0.089 & -0.275 & -0.089 & 1.046 & -0.031 & -0.048 & -0.031 & -0.047 & -0.071 & -0.091 \\
\hline A & 0.326 & -0.119 & -0.152 & -0.205 & -0.177 & -0.548 & -0.177 & -0.028 & 2.286 & -0.096 & -0.061 & -0.093 & -0.141 & -0.181 \\
\hline NLD & 0.617 & -0.226 & -0.287 & -0.388 & -0.335 & -1.037 & -0.336 & -0.053 & -0.117 & 3.463 & -0.115 & -0.176 & -0.266 & -0.343 \\
\hline PRT & .185 & -0.067 & -0.086 & -0.116 & -0.100 & -0.310 & -0.100 & -0.016 & -0.035 & -0.054 & 2.274 & -0.053 & -0.080 & -0.103 \\
\hline $\mathrm{P}$ & 03 & 147 & 188 & .254 & -0.219 & -0.678 & -0.219 & -0.035 & -0.077 & 119 & -0.075 & 3.419 & -0.174 & -0.224 \\
\hline $\mathrm{VE}$ & 628 & -0.230 & .292 & .395 & -0.341 & -1.056 & -0.342 & -0. & -0.119 & -0.185 & -0. & -0.180 & 5.059 & -0.349 \\
\hline JKG & .016 & -0.372 & -0.473 & o.640 & -0.551 & -1.708 & -0.553 & -0.087 & -0.193 & -0.300 & -0.190 & -0.291 & -0.438 & 6.308 \\
\hline
\end{tabular}

Welfare benefits

\begin{tabular}{|c|c|c|c|c|c|c|c|c|c|c|c|c|c|c|}
\hline & UT & EL & EN & FIN & RA & ER & $\mathrm{RC}$ & IRL & ITA & NLD & PRT & ESP & SWE & UKG \\
\hline$\overline{\mathrm{AUT}}$ & 772 & 40 & 094 & 0.277 & 211 & .710 & 435 & 0.042 & -0.335 & .078 & -0.055 & 0.097 & -0.142 & -0.278 \\
\hline$E L$ & 81 & 712 & 39 & 115 & 87 & .293 & 180 & 17 & .138 & .032 & 23 & 40 & 059 & 15 \\
\hline EN & 217 & .051 & 0.640 & 137 & -0.105 & -0.351 & .215 & .021 & .166 & -0.039 & .027 & .048 & .070 & .138 \\
\hline FIN & 253 & -0.059 & -0.054 & 1.870 & -0.122 & -0.410 & -0.251 & -0.024 & -0.193 & -0.045 & -0.032 & -0.056 & -0.082 & -0.160 \\
\hline FRA & 2 & -0.058 & -0.052 & -0.155 & 1.428 & -0.396 & -0.243 & -0.023 & -0.187 & -0.043 & -0.031 & -0 & -0.079 & -0.1 \\
\hline GER & -0.818 & -0.192 & -0.175 & -0.517 & -0.394 & 3.873 & -0.811 & -0.078 & -0.624 & -0.145 & -0.103 & -0.181 & -0.265 & -0.518 \\
\hline $\mathrm{RC}$ & 191 & 02 & .041 & -0.121 & -0.0 & -0 & 2.996 & -0.018 & -0. & -0 . & 24 & 2 & 62 & -0.121 \\
\hline $\mathrm{L}$ & 12 & 010 & .009 & -0.027 & -0.020 & -0.069 & -0.042 & 0.301 & -0.032 & -0 . & -0.005 & 9 & 14 & -0.02 \\
\hline $\mathrm{A}$ & 85 & -0.020 & -0.018 & -0.054 & -0.041 & -0.137 & -0.084 & -0.008 & 2.388 & -0.015 & -0.011 & -0.019 & -0.027 & -0.054 \\
\hline NLD & 0.160 & -0.038 & -0.034 & -0.101 & -0.077 & -0.259 & -0.159 & -0.015 & -0.122 & 0.542 & -0.020 & -0.036 & -0.052 & -0.101 \\
\hline PRT & -0.048 & -0.011 & -0.010 & -0.030 & -0.023 & -0.078 & -0.048 & -0.005 & -0.037 & -0.009 & 0.397 & -0.011 & -0.016 & -0.030 \\
\hline ESP & .105 & -0.025 & -0.022 & -0.066 & -0.050 & -0.169 & -0.104 & -0.010 & -0.080 & -0.019 & -0.013 & 0.689 & -0.034 & -0.066 \\
\hline $\mathrm{NE}$ & & 038 & .035 & -0.103 & -0.079 & -0.264 & -0.162 & -0 & -0.125 & -0.029 & -0.020 & -0.036 & 987 & -0.103 \\
\hline KG & 264 & -0.062 & .056 & -0.167 & -0.127 & -0.427 & -0.262 & -0.025 & -0.202 & -0.047 & -0.033 & -0.059 & -0.086 & 1.86 \\
\hline
\end{tabular}

1. Male, aged 25, primary education, arrived in 1990. 


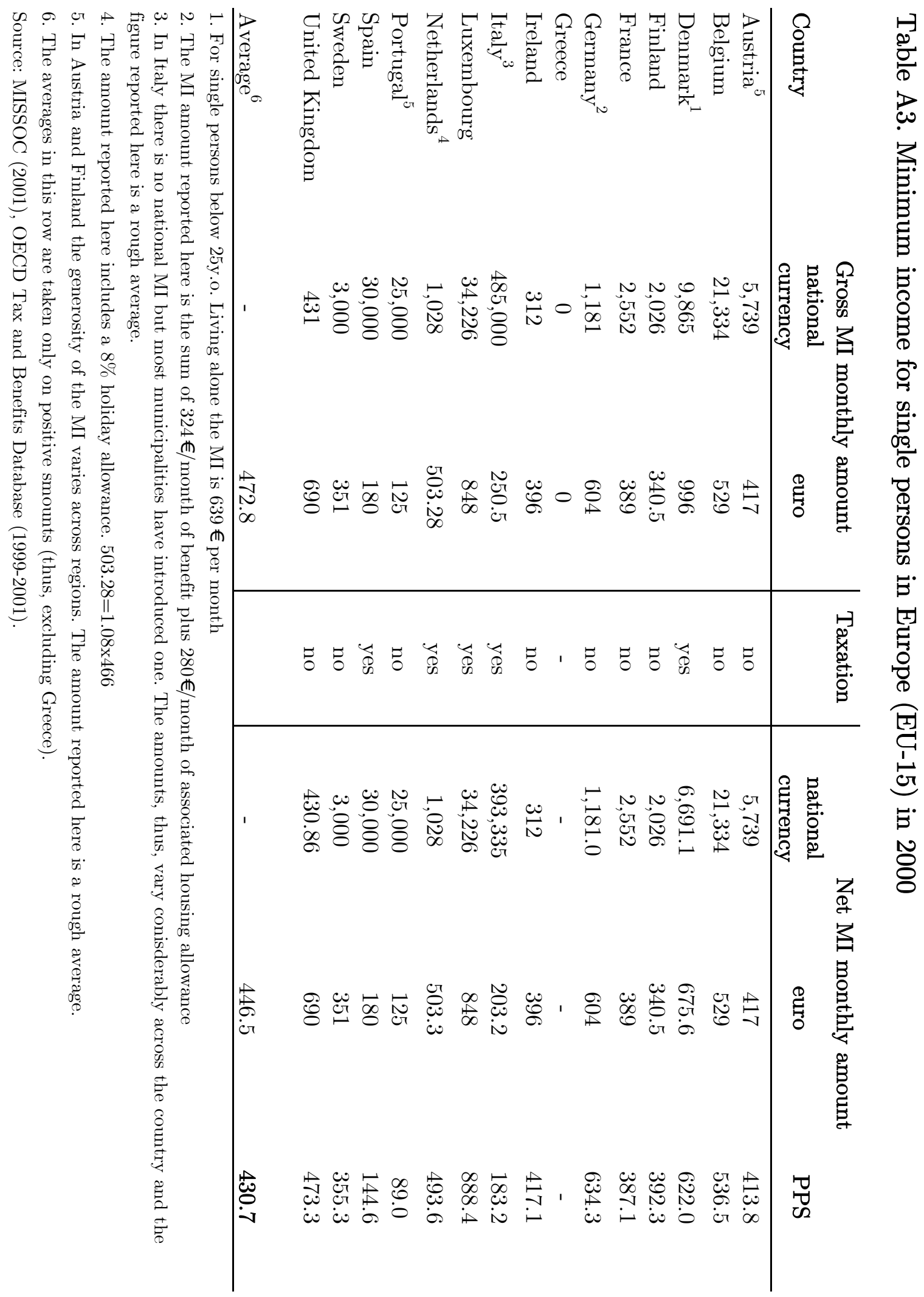


Table A4. Proportional increase of the average tax rate

\begin{tabular}{lccc} 
Country & $\begin{array}{c}0.5 \text { x Average } \\
\mathrm{MI}=215.35\end{array}$ & $\begin{array}{c}\text { Average } \\
\mathrm{MI}=430.7\end{array}$ & $\begin{array}{c}2 \times \text { Average } \\
\mathrm{MI}=861.4\end{array}$ \\
\hline Austria & -0.003 & 0.008 & 0.186 \\
Belgium & -0.003 & 0.002 & 0.167 \\
Denmark & -0.012 & -0.005 & 0.125 \\
Finland & -0.024 & -0.001 & 0.432 \\
France & -0.165 & -0.093 & 0.695 \\
Germany & -0.005 & 0.011 & 0.165 \\
Greece & 0.019 & 0.234 & 1.666 \\
Ireland & -0.002 & 0.067 & 0.565 \\
Italy & 0.011 & 0.109 & 0.781 \\
Netherlands & -0.009 & 0.023 & 0.325 \\
Portugal & 0.012 & 0.172 & 0.945 \\
Spain & 0.010 & 0.113 & 0.717 \\
United Kingdom & -0.039 & -0.001 & 0.262 \\
& & & \\
Average & -0.033 & 0.021 & 0.419 \\
Centralised & -0.014 & 0.027 & 0.338
\end{tabular}

